Supporting Information

\title{
Comparison and Mechanism Study of Antibacterial Activity of
}

\section{Cationic and Neutral Oligo-thiophene-ethynylene}

Wei Liao ${ }^{1,3}$, Xiaoyi Shi ${ }^{2}$, Lian-gang Zhuo ${ }^{1,3,4}$, Xia Yang ${ }^{1,3,4}$, Peng Zhao ${ }^{1,3}$, Wentao Kan $^{1,3}$, Guanquan Wang ${ }^{1,3}$, Hongyuan Wei ${ }^{1,3,4}$, Yuchuan Yang ${ }^{1,3,4}$, Zhijun Zhou ${ }^{3,5}$, and Jing Wang ${ }^{1,3 *}$

${ }^{1}$ Institute of Nuclear Physics and Chemistry (INPC), China Academy of Engineering Physics (CAEP), Mianyang, 621999, P. R. China

${ }^{2}$ West China Hospital of Sichuan University Cleaning and Disinfection Supply Center, Chengdu, Sichuan Province, People's Republic of China 610041

${ }^{3}$ Key Laboratory of Nuclear Medicine and Molecular Imaging of Sichuan Province, Mianyang, 621999, P. R. China

${ }^{4}$ Collaborative Innovation Center of Radiation Medicine of Jiangsu, Higher Education Institutions, Suzhou, 215123, P. R. China

${ }^{5}$ Department of Nuclear Medicine, The Affiliated Hospital of Southwest Medical University, Luzhou, Sichuan 646000, People's Republic of China

\section{Corresponding Author}

* Phone: (86)816-2485484

E-Mail: wangjing_es@caep.cn 


\section{Contents}

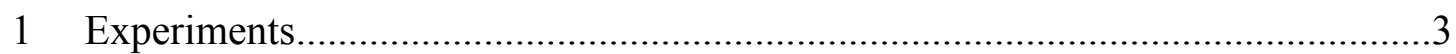

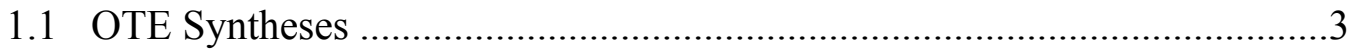

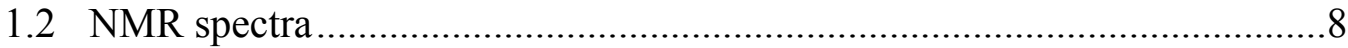

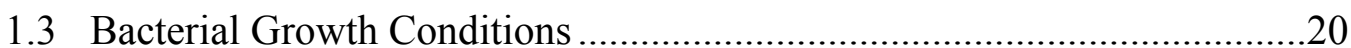

1.4 Bacterial Killing Experiments Uusing Flow Cytometry ..........................20

1.5 Bacterial Killing Experiments Uusing Plate Counting .............................20

1.6 Preparation of Fluorescein-Loaded Vesicles and Vesicle Leakage Assays 21

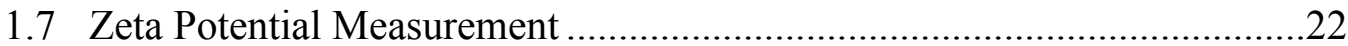



1.9 Reactive oxygen species (ROS) measurements.......................................23

1.10 Observation of Cell Morphology ......................................................23

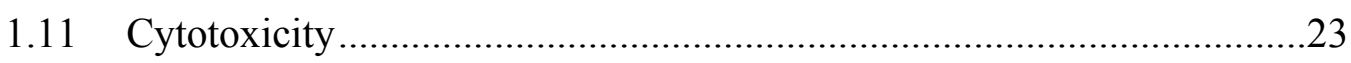

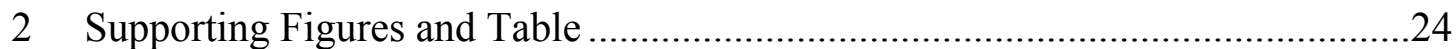




\section{Experiments}

\subsection{OTE Syntheses}

Scheme S1. Syntheses of OTE-1 and OTE-2.



S1

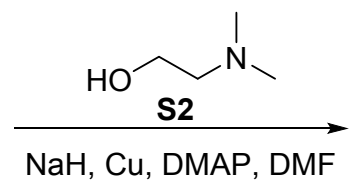

$\mathrm{NaH}, \mathrm{Cu}, \mathrm{DMAP}, \mathrm{DMF}$<smiles>CN(C)CCOc1cccs1</smiles>

S3

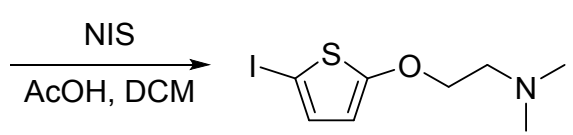

S4

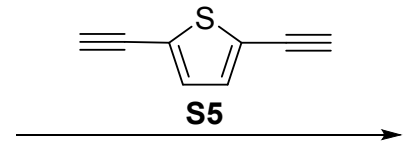

Cul, $\mathrm{Pd}\left(\mathrm{PPh}_{3}\right)_{2} \mathrm{Cl}_{2}$ $\mathrm{NEt}_{3}, \mathrm{DCM}$

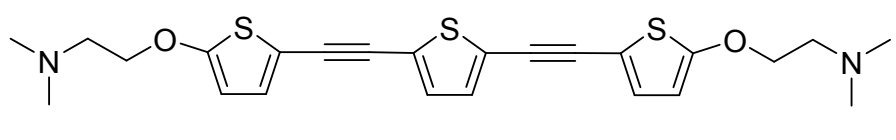

OTE-1

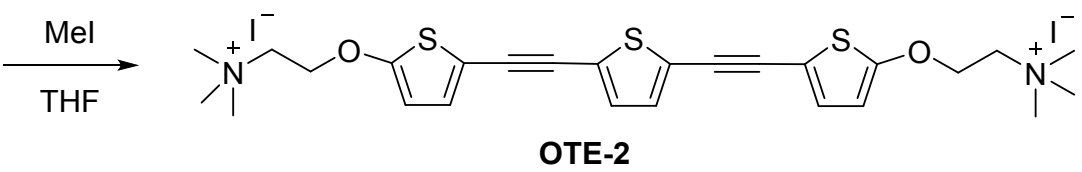

Compound S3. NaH (0.72 g, $30 \mathrm{mmol})$ and dry dioxane were mixed and degassed by purging with argon gas for 5 minutes, and the mixture was stirred at $10{ }^{\circ} \mathrm{C}$ for 10 min, then compound S2 $2.2 \mathrm{~mL}$ were added to the mixture slowly and stirred for 40 min, copper power (0.32 g, $5 \mathrm{mmol}), \mathrm{CuI}(0.95 \mathrm{~g}, 5 \mathrm{mmml}), \mathrm{LiCl}(0.85 \mathrm{~g}, 20 \mathrm{mmol})$ and 2-iodothiophene $\mathbf{S 1}(1.1 \mathrm{~mL}, 10 \mathrm{mmol})$ were added under argon gas protection, then the mixture were heated to $100{ }^{\circ} \mathrm{C}$ and stirred for $18 \mathrm{~h}$. Until the reaction completed, cool water was added and the solid was removed via filtration, the filtrate was extracted with DCM three times and collected organic phase was washed by brine and dried by $\mathrm{Na}_{2} \mathrm{SO}_{4}$. The solid was removed via filtration and the filtrate was concentrated in vacuum. The residue was purified by flash column chromatography with silica gel to give compound $\mathbf{S 3}$ (1.06 g, $6.2 \mathrm{mmol}, 62 \%)$. ${ }^{1} \mathrm{H}$ NMR (500 MHz, $\left.\mathrm{CDCl}_{3}\right) \delta 6.70(\mathrm{dd}, J=5.8,3.8 \mathrm{~Hz}, 1 \mathrm{H}), 6.54(\mathrm{dd}, J=5.8,1.5 \mathrm{~Hz}, 1 \mathrm{H}), 6.23(\mathrm{dd}, J=$ $3.8,1.5 \mathrm{~Hz}, 1 \mathrm{H}), 4.13(\mathrm{t}, J=5.7 \mathrm{~Hz}, 2 \mathrm{H}), 2.71(\mathrm{t}, J=5.7 \mathrm{~Hz}, 2 \mathrm{H}), 2.33(\mathrm{~s}, 6 \mathrm{H}) .{ }^{13} \mathrm{C}$ NMR (126 MHz, $\left.\mathrm{CDCl}_{3}\right) \delta 165.44,124.64,112.04,104.95,71.73,58.01,45.79$. HRMS $(\mathrm{ESI}+, m / z)$ calcd for $\mathrm{C}_{8} \mathrm{H}_{14} \mathrm{NOS},[\mathrm{M}+\mathrm{H}]^{+}$172.0791, found 172.0790. 
Compound S4. Compound S3 (10.1 g, $59 \mathrm{mmol})$, DCM $50 \mathrm{~mL}$ were mixed and degassed by purging with argon gas for 5 minutes, and N-iodosuccinimide (NIS, $18 \mathrm{~g}$, $80 \mathrm{mmol}$ ) was added at $0{ }^{\circ} \mathrm{C}$. The mixture was stirred at $0{ }^{\circ} \mathrm{C}$ for $2 \mathrm{~h}$ and at room temperature overnight. The mixture was washed with $\mathrm{NaHCO}_{3}$ solution and extracted with DCM three times. The collected organic phase was dried by $\mathrm{Na}_{2} \mathrm{SO}_{4}$. The solid was removed via filtration and the filtrate was concentrated in vacuum. The residue was purified by flash column chromatography with silica gel to give compound $\mathbf{S} \mathbf{4}$ (8.1 g, $27.3 \mathrm{mmol}, 46 \%)$. HRMS (ESI+, $m / z)$ calcd for $\mathrm{C}_{8} \mathrm{H}_{13} \mathrm{INOS},[\mathrm{M}+\mathrm{H}]^{+}$ 297.9757, found 297.9751 .

Compound OTE-1. Compound S4 (3.68 g, $12.4 \mathrm{mmol}), \mathrm{CuI}(0.23 \mathrm{~g}, 1.2 \mathrm{mmol})$, $\mathrm{Pd}\left(\mathrm{PPh}_{3}\right) \mathrm{Cl}_{2}(0.29 \mathrm{~g}, 0.41 \mathrm{mmol})$, diisopropylamine $20 \mathrm{~mL}, \mathrm{CHCl}_{3} 20 \mathrm{~mL}$ were mixed and degassed by purging with argon gas for 5 minutes. Compound $\mathbf{S 5}^{\mathbf{1}}(0.792$ g, $6.0 \mathrm{mmol}$ ) was added to the mixture and the miture as heated to $50{ }^{\circ} \mathrm{C}$ and stirred for $24 \mathrm{~h}$. The solid was removed via filtration and the filtrate was concentrated. The residue was purified by flash column chromatography with silica gel to afford compound OTE-1 (0.93 g, $2.0 \mathrm{mmol}, 33 \%) .{ }^{1} \mathrm{H}$ NMR (600 MHz, $\left.\mathrm{CDCl}_{3}\right) \delta 7.16(\mathrm{~d}, J$ $=5.6 \mathrm{~Hz}, 2 \mathrm{H}), 7.08(\mathrm{~s}, 2 \mathrm{H}), 6.75(\mathrm{~d}, J=5.6 \mathrm{~Hz}, 2 \mathrm{H}), 4.33(\mathrm{t}, J=5.8 \mathrm{~Hz}, 4 \mathrm{H}), 2.74(\mathrm{t}$, $J=5.8 \mathrm{~Hz}, 4 \mathrm{H}), 2.36(\mathrm{~s}, 12 \mathrm{H}) .{ }^{13} \mathrm{C} \mathrm{NMR}\left(151 \mathrm{MHz}, \mathrm{CDCl}_{3}\right) \delta 159.98,131.42,126.35$, 124.70, 117.89, 100.83, 88.09, 85.78, 70.19, 58.33, 46.01. HRMS (ESI+, $m / 2 z)$ calcd for $1 / 2 \mathrm{C}_{24} \mathrm{H}_{28} \mathrm{~N}_{2} \mathrm{O}_{2} \mathrm{~S}_{3}, 1 / 2[\mathrm{M}+2 \mathrm{H}]^{2+} 236.0651$, found 236.0636 .

Compound OTE-2. Compound OTE-1 (0.50 g, $1.1 \mathrm{mmol})$, MeI (543 $\mu \mathrm{L}, 8.8 \mathrm{mmol})$ were dissolvedin $4 \mathrm{~mL}$ THF and stirrd at room temperature for $3 \mathrm{~h}$. The mixture was concentrated to give OTE-2 (0.67 mg, $0.89 \mathrm{mmol}, 81 \%) .{ }^{1} \mathrm{H}$ NMR (400 MHz, DMSO)

1 Seidler, A.; Svoboda, J.; Dekoj, V.; Chocholoušová, J. V.; Vacek, J.; Stará, I. G.; Starý, I. The synthesis of $\pi$-electron molecular rods with a thiophene or thieno[3,2-b]thiophene core unit and sulfur alligator clips. Tetrahedron Lett. 2013, 54, 2795-2798. 
$\delta 7.70(\mathrm{~d}, J=5.5 \mathrm{~Hz}, 2 \mathrm{H}), 7.33(\mathrm{~s}, 2 \mathrm{H}), 7.17(\mathrm{~d}, J=5.5 \mathrm{~Hz}, 2 \mathrm{H}), 4.65(\mathrm{~s}, 4 \mathrm{H}), 3.81(\mathrm{~s}$, 4H), 3.22 (s, 18H). ${ }^{13} \mathrm{C}$ NMR (100 MHz, DMSO) $\delta 166.72,133.16,129.34,123.93$, 117.92, 100.07, 88.23, 86.43, 65.67, 64.66, 53.72. HRMS (ESI+, $m / 2 z)$ calcd for $1 / 2 \mathrm{C}_{26} \mathrm{H}_{32} \mathrm{~N}_{2} \mathrm{O}_{2} \mathrm{~S}_{3}, 1 / 2[\mathrm{M}]^{2+} 250.0807$, found 250.0778 .

Scheme S2. Syntheses of OTE-3 and OTE-4.

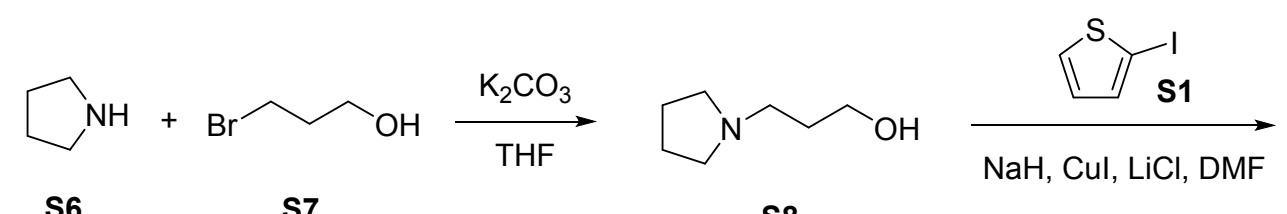

S6

s7

S8

$\stackrel{\mathrm{S}}{\mathrm{S}}$

s9<smiles>Ic1ccc(OCCCN2CCCC2)s1</smiles>

S10

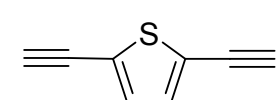

S5

Cul, $\mathrm{Pd}\left(\mathrm{PPh}_{3}\right)_{2} \mathrm{Cl}_{2}$ $\mathrm{NEt}_{3}, \mathrm{DCM}$<smiles>C(#Cc1ccc(OCCCN2CCCC2)s1)c1ccc(C#Cc2ccc(OCCCN3CCCC3)s2)s1</smiles>

OTE-3

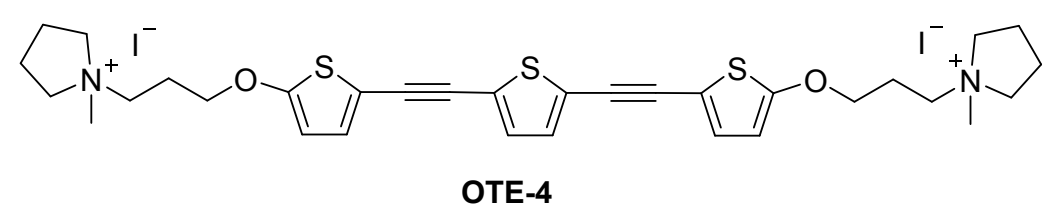

Compound S8. $\mathrm{K}_{2} \mathrm{CO}_{3}(41.5 \mathrm{~g}, 300 \mathrm{mmol})$, THF $80 \mathrm{~mL}$, pyrrolidine (33 mL, 394 mmol) were mixed and stirred at $0{ }^{\circ} \mathrm{C}$ for $15 \mathrm{~min}$, then the 3-bromopropan-1-ol S7 (18 $\mathrm{mL}, 202 \mathrm{mmol}$ ) was added to the mixture slowly, then the mixture was stirred at room temperature overnight. The solid was removed via filtration and the filtrate was concentrated in vacuum. The residue was purified via distillation in vacuum to give compound S8 $15 \mathrm{~mL} .{ }^{1} \mathrm{H}$ NMR $\left(500 \mathrm{MHz}, \mathrm{CDCl}_{3}\right) \delta 5.61-5.24(\mathrm{~m}, 1 \mathrm{H}), 3.75(\mathrm{t}, J=$ $5.6 \mathrm{~Hz}, 2 \mathrm{H}), 2.69(\mathrm{t}, J=6.2 \mathrm{~Hz}, 2 \mathrm{H}), 2.56(\mathrm{td}, J=5.5,4.8,2.2 \mathrm{~Hz}, 4 \mathrm{H}), 1.80-1.75$ (m, 4H), $1.75-1.69(\mathrm{~m}, 2 \mathrm{H}) .{ }^{13} \mathrm{C}$ NMR $\left(126 \mathrm{MHz}, \mathrm{CDCl}_{3}\right) \delta$ 63.46, 55.57, 54.05, 
29.72, 23.25. HRMS (ESI+, $m / z)$ calcd for $\mathrm{C} \mathrm{H}_{16} \mathrm{NO},[\mathrm{M}+\mathrm{H}]^{+} 130.1226$, found 130.1225 .

Compound S9. NaH (1.76 g, $73 \mathrm{mmol})$ and dry DMF were mixed and degassed by purging with argon gas for 5 minutes, and the mixture was stirred at $10{ }^{\circ} \mathrm{C}$ for 10 min, then compound $\mathbf{S 8} 5.3 \mathrm{~mL}$ was added to the mixture slowly and stirred for 30 min, copper power (1.27 g, $20 \mathrm{mmol}), \mathrm{CuI}(3.81 \mathrm{~g}, 20 \mathrm{mmml}), \mathrm{LiCl}(0.85 \mathrm{~g}, 80 \mathrm{mmol})$ and 2-iodothiophene $\mathbf{S 1}$ (5.3 $\mathrm{mL}, 48 \mathrm{mmol})$ were added under argon gas protection, then the mixture were heated to $100{ }^{\circ} \mathrm{C}$ and stirred for $18 \mathrm{~h}$. Until the reaction completed, cool water was added and the solid was removed via filtration, the filtrate was extracted with DCM three times and the collected organic phase was washed by brine and dried by $\mathrm{Na}_{2} \mathrm{SO}_{4}$. The solid was removed via filtration and the filtrate was concentrated in vacuum. The residue was purified by flash column chromatography with silica gel to give compound S9 (3.8 g, $18.0 \mathrm{mmol}, 38 \%)$. ${ }^{1} \mathrm{H}$ NMR (500 MHz, Chloroform-d) $\delta 6.70(\mathrm{dd}, J=5.8,3.7 \mathrm{~Hz}, 1 \mathrm{H}), 6.53(\mathrm{dd}, J=5.8,1.5 \mathrm{~Hz}, 1 \mathrm{H}), 6.20$ $(\mathrm{dd}, J=3.8,1.5 \mathrm{~Hz}, 1 \mathrm{H}), 4.09(\mathrm{t}, J=6.4 \mathrm{~Hz}, 2 \mathrm{H}), 2.65-2.59(\mathrm{~m}, 2 \mathrm{H}), 2.57-2.49(\mathrm{~m}$, 4H), 2.00 (p, $J=6.6 \mathrm{~Hz}, 2 \mathrm{H}), 1.79$ (p, $J=3.2 \mathrm{~Hz}, 4 \mathrm{H}) .{ }^{13} \mathrm{C} \mathrm{NMR}\left(126 \mathrm{MHz}, \mathrm{CDCl}_{3}\right)$ $\delta 165.67,124.68,111.79,104.67,72.32,54.23,52.94,28.74,23.47$. HRMS (ESI+, $m / z$ ) calcd for $\mathrm{C}_{11} \mathrm{H}_{18} \mathrm{NOS},[\mathrm{M}+\mathrm{H}]^{+}$212.1104, found 212.1099.

Compound S10. Compound S9 (2.2 g, $10.4 \mathrm{mmol})$, acetic acid (1.9 mL, $33.2 \mathrm{mmol})$, DCM $6 \mathrm{~mL}$ were mixed and degassed by purging with argon gas for 5 minutes, and $\mathrm{N}$-iodosuccinimide (NIS, $3.5 \mathrm{~g}, 15.6 \mathrm{mmol}$ ) was added at $0{ }^{\circ} \mathrm{C}$. The mixture was stirred at $0{ }^{\circ} \mathrm{C}$ for $3 \mathrm{~h}$ and at room temperature overnight. The mixture was washed with $\mathrm{NaHCO}_{3}$ solution and extracted with DCM three times. The collected organic phase was dried by $\mathrm{Na}_{2} \mathrm{SO}_{4}$. The solid was removed via filtration and the filtrate was concentrated in vacuum. The residue was purified by flash column chromatography with silica gel to give compound S10 (0.82 g, $2.43 \mathrm{mmol}$, 23\%). HRMS (ESI+, $m / z$ ) calcd for $\mathrm{C}_{11} \mathrm{H}_{17} \mathrm{INOS},[\mathrm{M}+\mathrm{H}]^{+} 338.0070$, found 338.0068.

Compound OTE-3. Compound S10 (1.48 g, $4.4 \mathrm{mmol})$, CuI (0.076 g, $0.40 \mathrm{mmol})$, $\mathrm{Pd}\left(\mathrm{PPh}_{3}\right)_{2} \mathrm{Cl}_{2}(0.126 \mathrm{~g}, 0.18 \mathrm{mmol})$, diisopropylamine $2 \mathrm{~mL}, \mathrm{CHCl}_{3} 4 \mathrm{~mL}$ were 
mixed and degassed by purging with argon gas for 5 minutes. Compound S5 (0.264 g, $2.0 \mathrm{mmol}$ ) was added to the mixture and the miture as heated to $50{ }^{\circ} \mathrm{C}$ and stirred for $24 \mathrm{~h}$. The solid was removed via filtration and the filtrate was concentrated. The residue was purified by flash column chromatography with silica gel to afford compound OTE-3 (0.28 g, $0.51 \mathrm{mmol}, 26 \%) .{ }^{1} \mathrm{H} \mathrm{NMR}\left(600 \mathrm{MHz}, \mathrm{CDCl}_{3}\right) \delta 7.07(\mathrm{~s}$, 2H), $6.95(\mathrm{~d}, J=4.0 \mathrm{~Hz}, 2 \mathrm{H}), 6.12(\mathrm{~d}, J=4.0 \mathrm{~Hz}, 2 \mathrm{H}), 4.13(\mathrm{t}, J=6.3 \mathrm{~Hz}, 4 \mathrm{H}), 2.63$ $(\mathrm{t}, J=7.4 \mathrm{~Hz}, 4 \mathrm{H}), 2.58-2.52(\mathrm{~m}, 8 \mathrm{H}), 2.02(\mathrm{dt}, J=13.3,6.5 \mathrm{~Hz}, 4 \mathrm{H}), 1.83-1.77$ $(\mathrm{m}, 8 \mathrm{H}) .{ }^{13} \mathrm{C} \mathrm{NMR}\left(151 \mathrm{MHz}, \mathrm{CDCl}_{3}\right) \delta 166.84,131.53,131.45,124.48,108.60$, $105.11,88.20,83.76,72.23,54.19,52.74,28.52,23.45$. HRMS (ESI+, $m / z)$ calcd for $\mathrm{C}_{30} \mathrm{H}_{35} \mathrm{~N}_{2} \mathrm{O}_{2} \mathrm{~S}_{3},[\mathrm{M}+\mathrm{H}]^{+}$551.1855, found 551.1846.

Compound OTE-4. Compound OTE-3 (0.284 g, 0.52 mmol), MeI (193 $\mu \mathrm{L}, 3.1$ mmol) were dissolvedin $4 \mathrm{~mL}$ THF and stirrd at room temperature for $3 \mathrm{~h}$. The mixture was concentrated to give OTE-4 (0.368 g, 0.44mmol, 85\%). ${ }^{1} \mathrm{H}$ NMR (400 MHz, DMSO) $\delta 7.36(\mathrm{~s}, 2 \mathrm{H}), 7.20(\mathrm{~d}, J=4 \mathrm{~Hz}, 2 \mathrm{H}), 6.42(\mathrm{~d}, J=4 \mathrm{~Hz}, 2 \mathrm{H}), 4.24(\mathrm{~d}, J$ $=4 \mathrm{~Hz}, 4 \mathrm{H}), 3.54-3.50(\mathrm{~m}, 12 \mathrm{H}), 3.04(\mathrm{~s}, 6 \mathrm{H}), 2.28-2.21(\mathrm{~m}, 4 \mathrm{H}), 2.11(\mathrm{~s}, 8 \mathrm{H}) .{ }^{13} \mathrm{C}$ NMR (100 MHz, DMSO) $\delta 166.35,133.47,133.41,123.82,107.60,106.70,88.76$, 84.03, 71.20, 64.10, 60.64, 48.10, 23.68, 21.57. HRMS (ESI+, $m / 2 z)$ calcd for $1 / 2 \mathrm{C}_{32} \mathrm{H}_{40} \mathrm{~N}_{2} \mathrm{O}_{2} \mathrm{~S}_{3}, 1 / 2[\mathrm{M}]^{2+} 290.1120$, found 290.1128 . 
1.2 NMR spectra

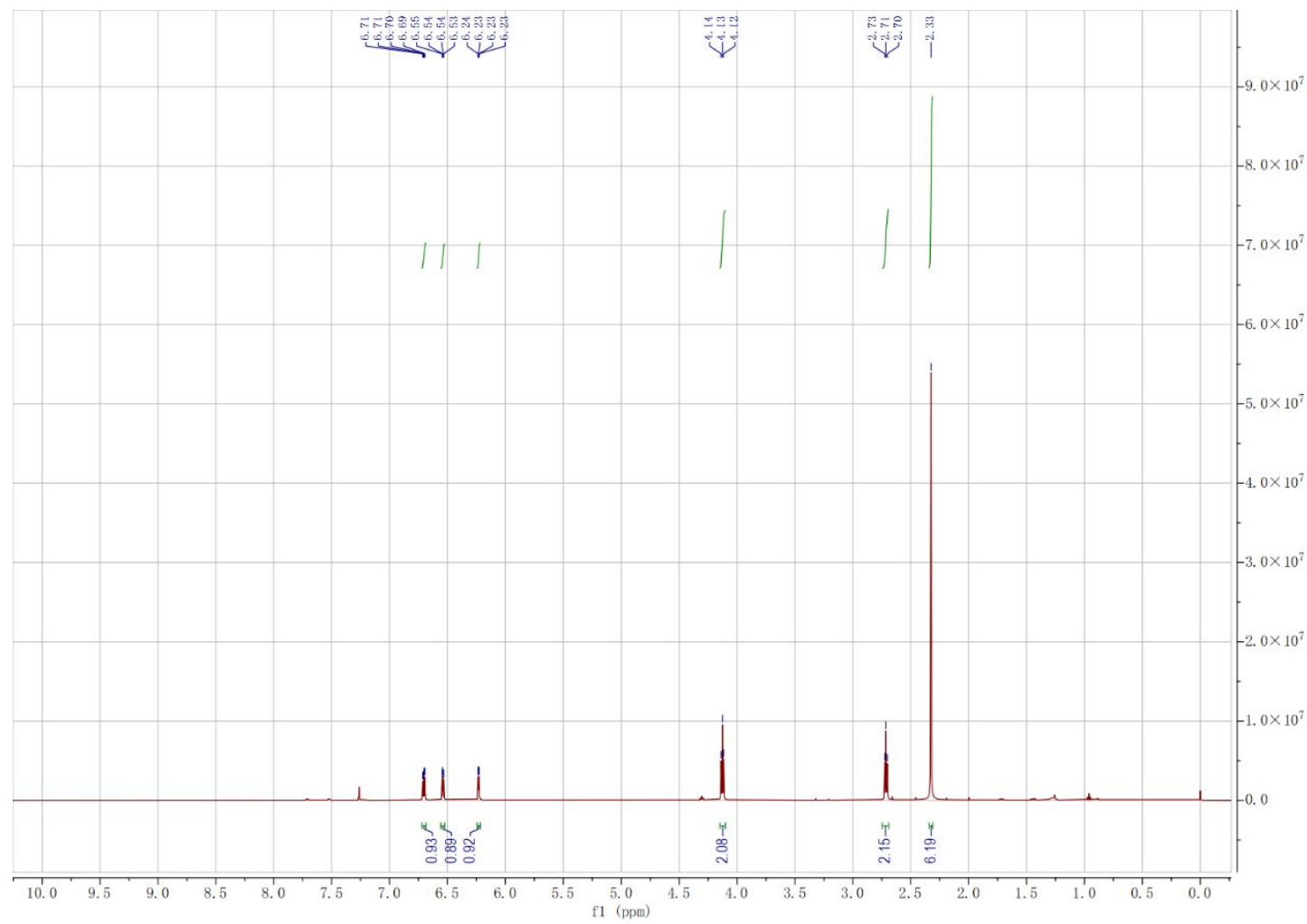

Figure S1. ${ }^{1} \mathrm{H}$ NMR of S3.

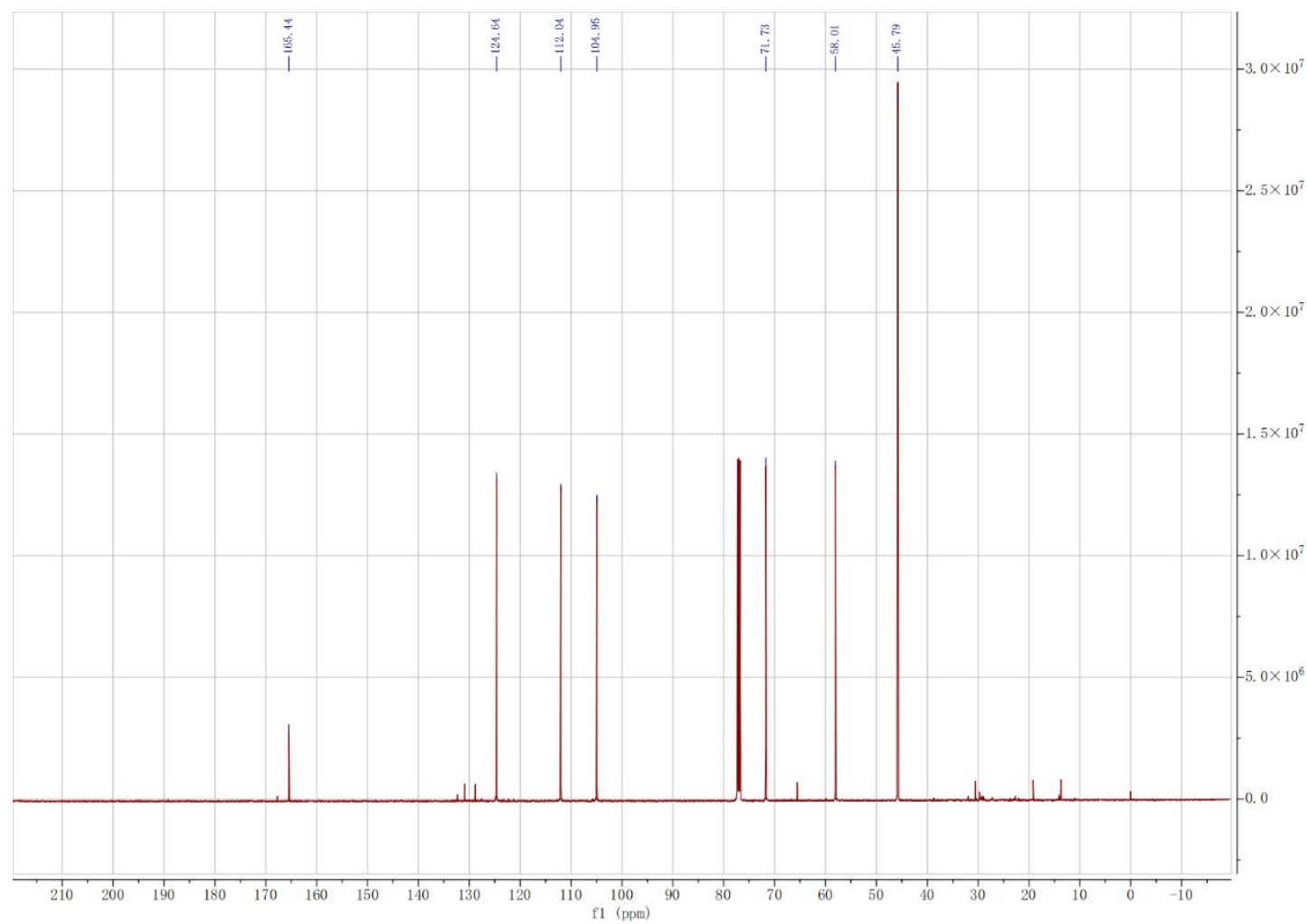

Figure S2. ${ }^{13} \mathrm{C}$ NMR of S3. 


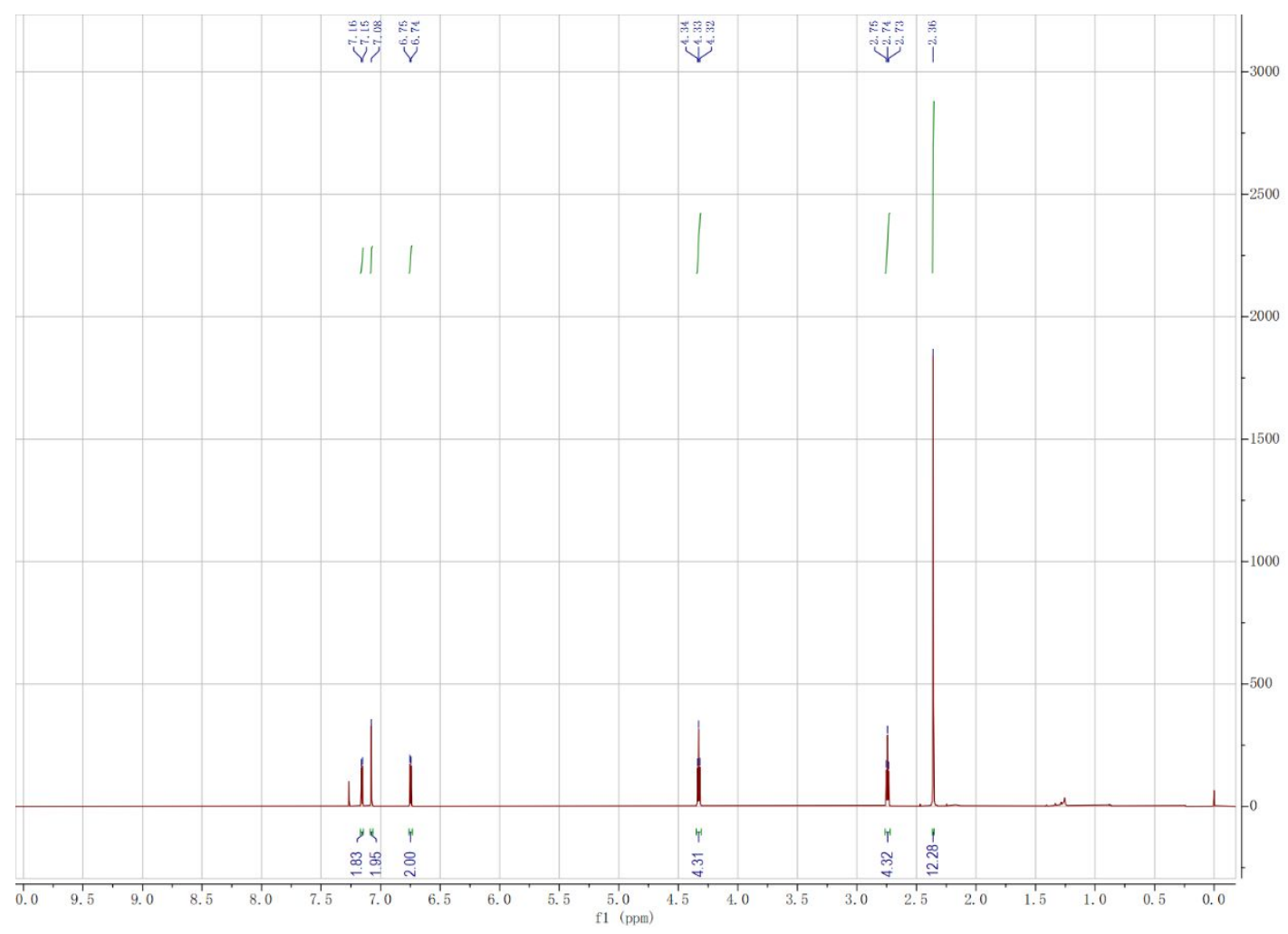

Figure S3. ${ }^{1} \mathrm{H}$ NMR of OTE-1.

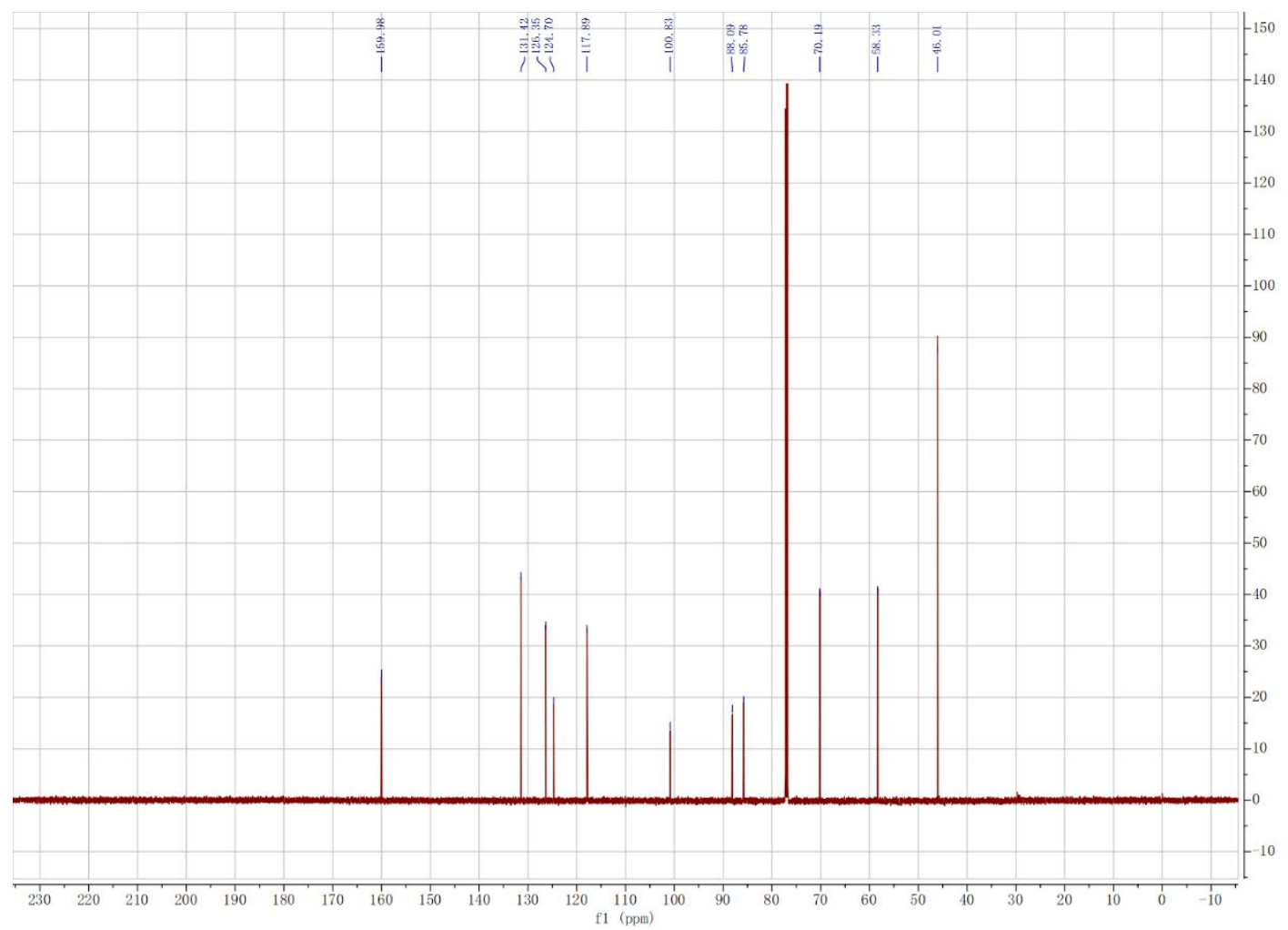

Figure S4. ${ }^{13} \mathrm{C}$ NMR of OTE-1. 


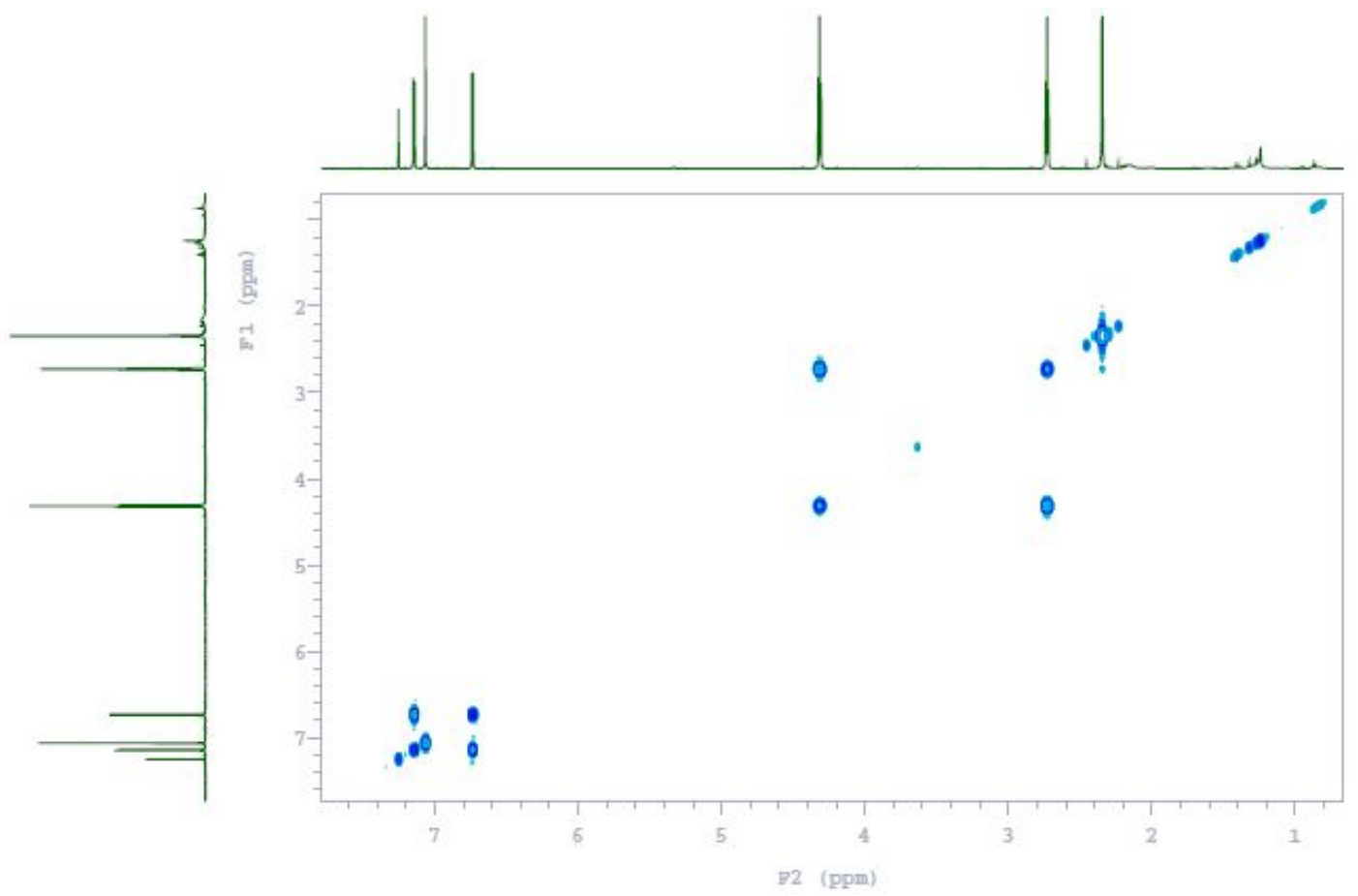

Figure S5. ${ }^{1} \mathrm{H}-{ }^{1} \mathrm{H}$ COSY of OTE-1.

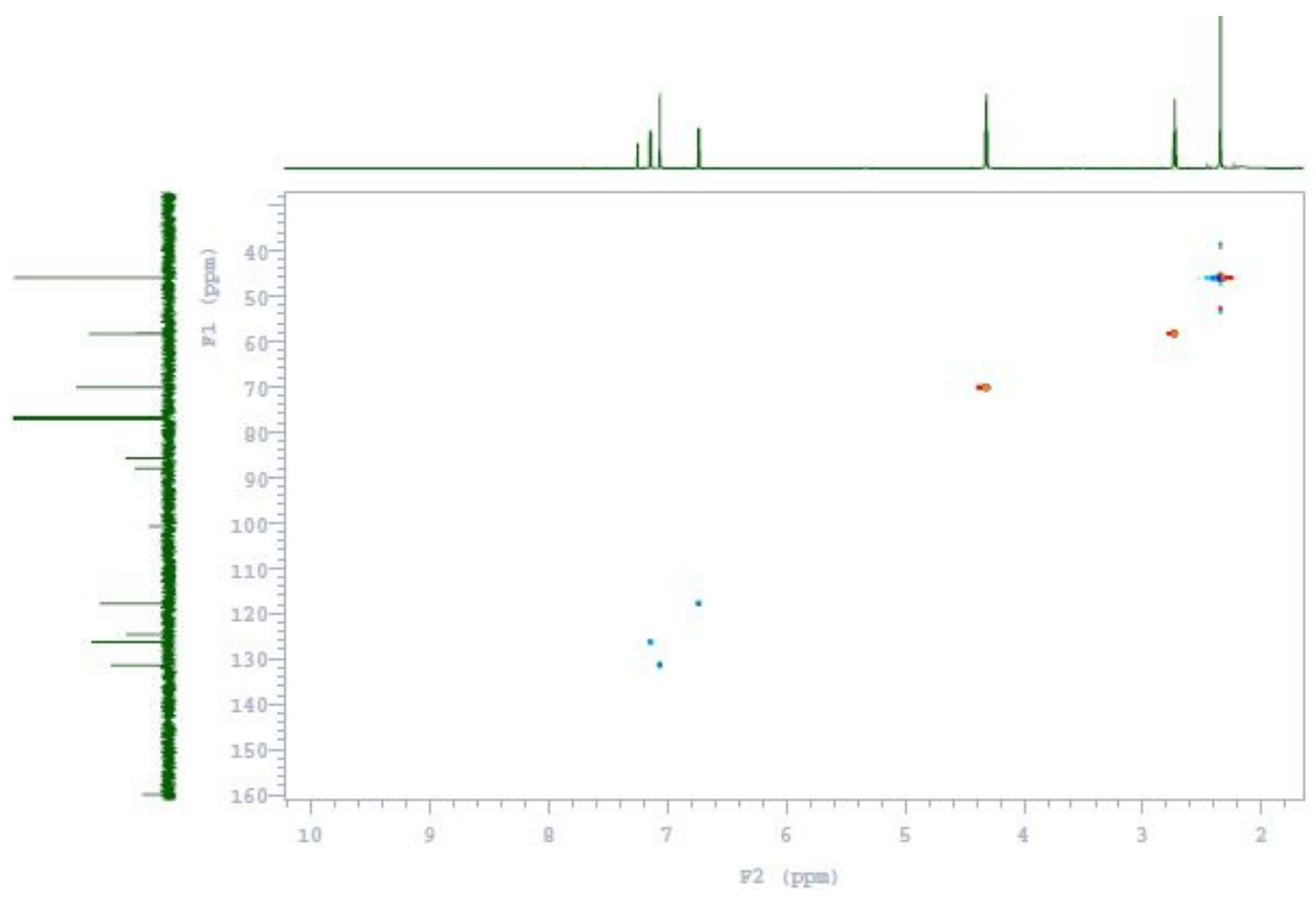

Figure S6. ${ }^{1} \mathrm{H}-{ }^{13} \mathrm{C}$ HSQC of OTE-1. 


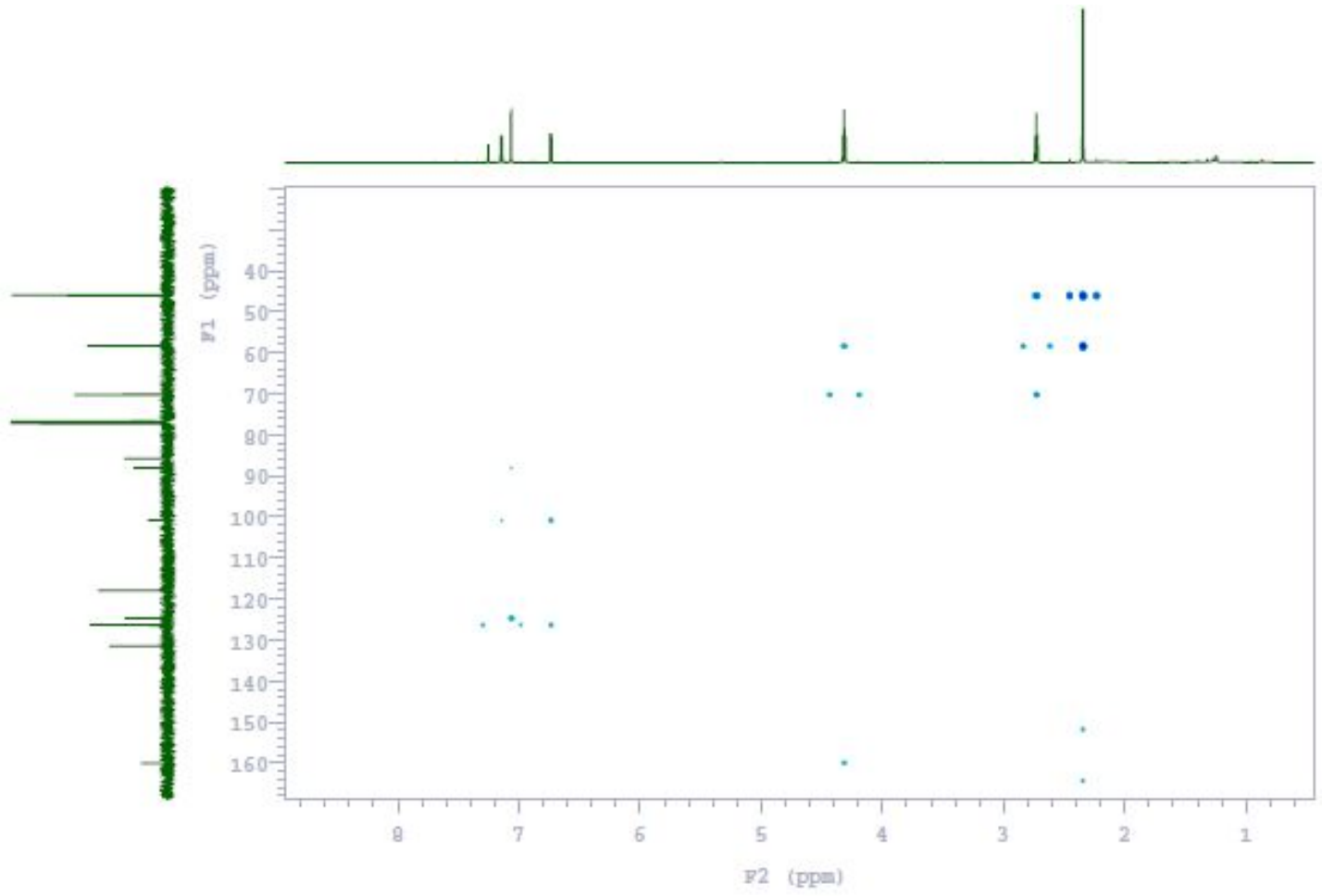

Figure $\mathbf{S 7} .{ }^{1} \mathrm{H}-{ }^{13} \mathrm{C}$ HMBC of OTE-1.

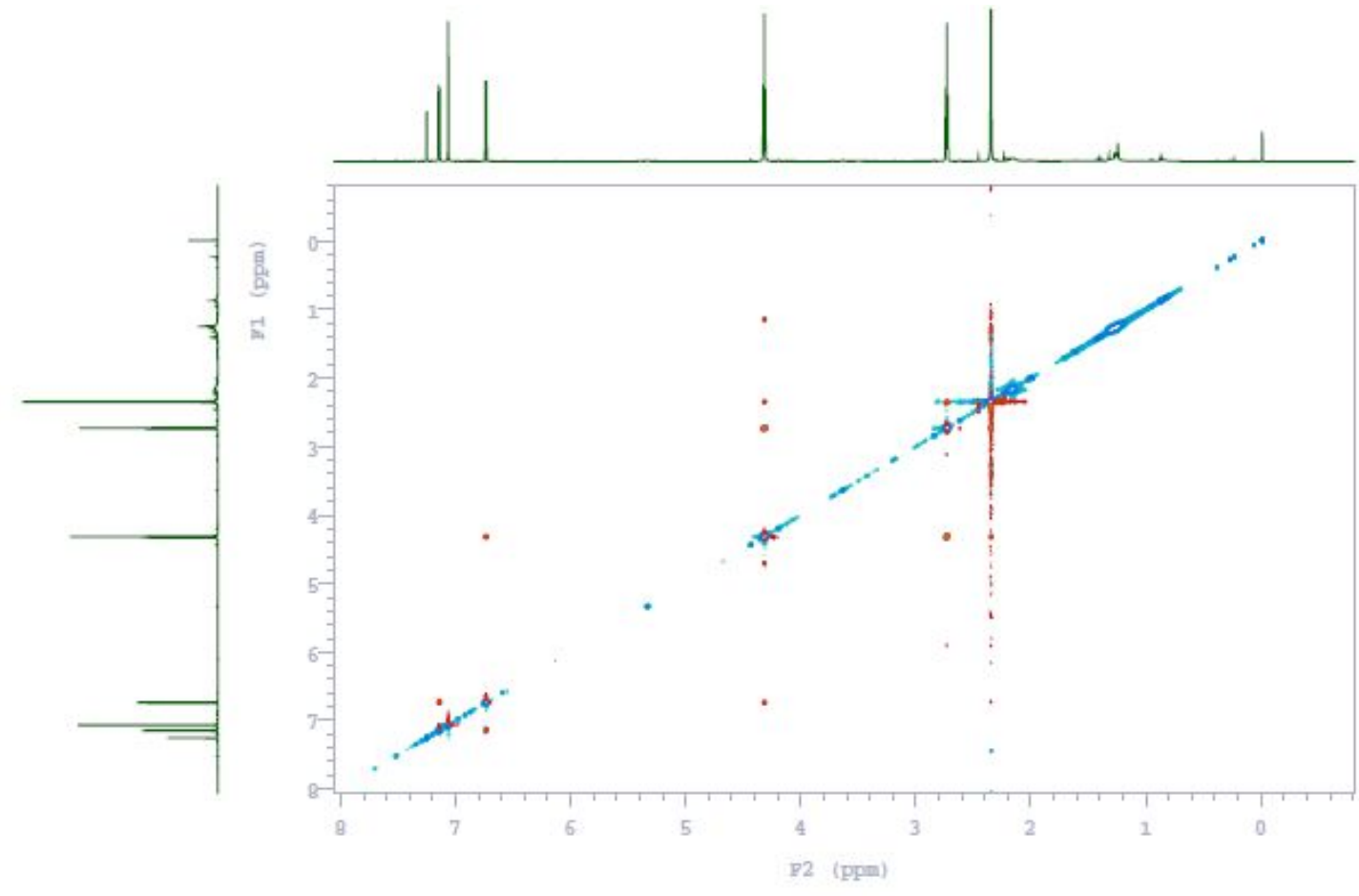

Figure S8. ${ }^{1} \mathrm{H}-{ }^{1} \mathrm{H}$ NOESY of OTE-1. 


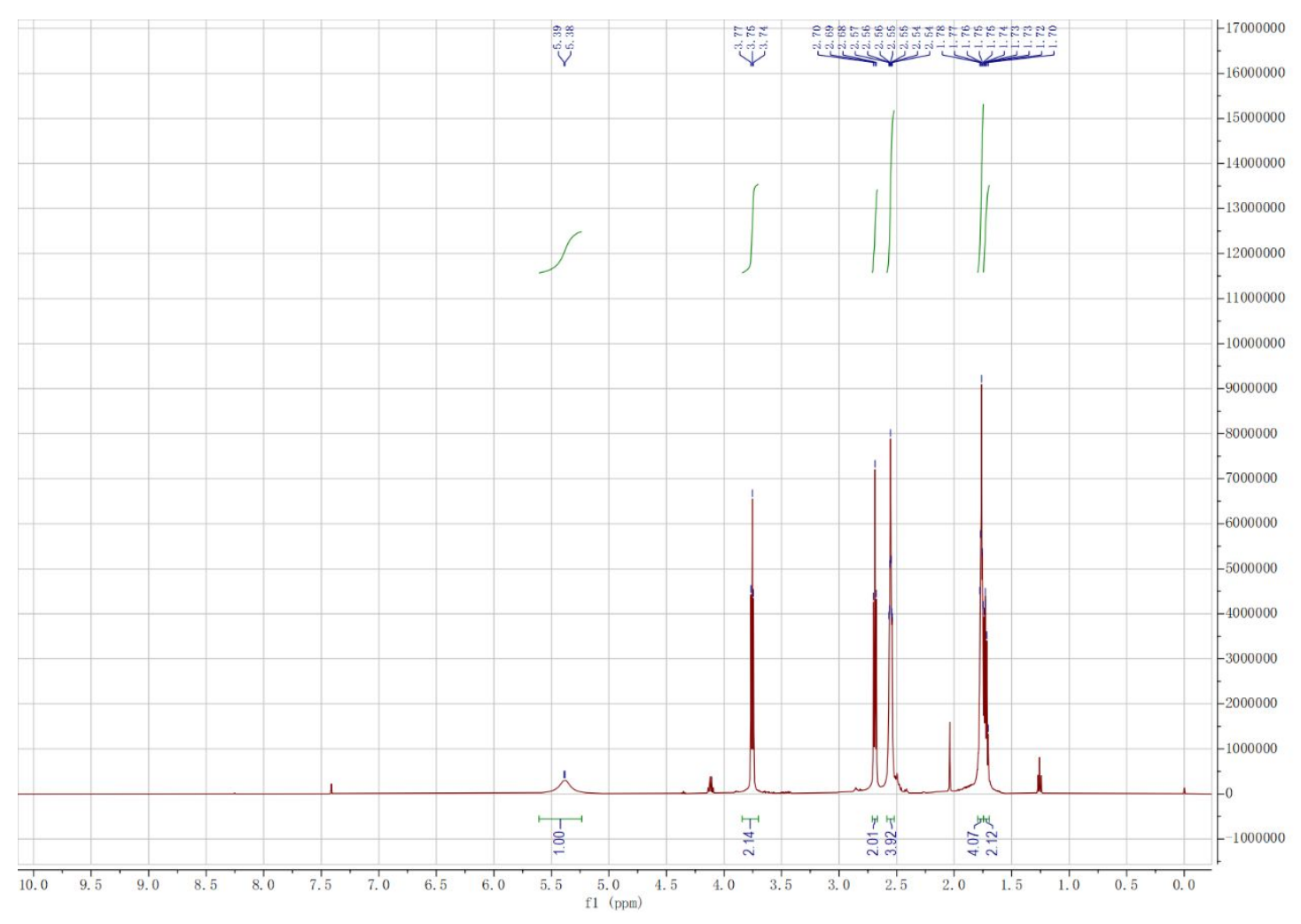

Figure S9. ${ }^{1} \mathrm{H}$ NMR of S8.

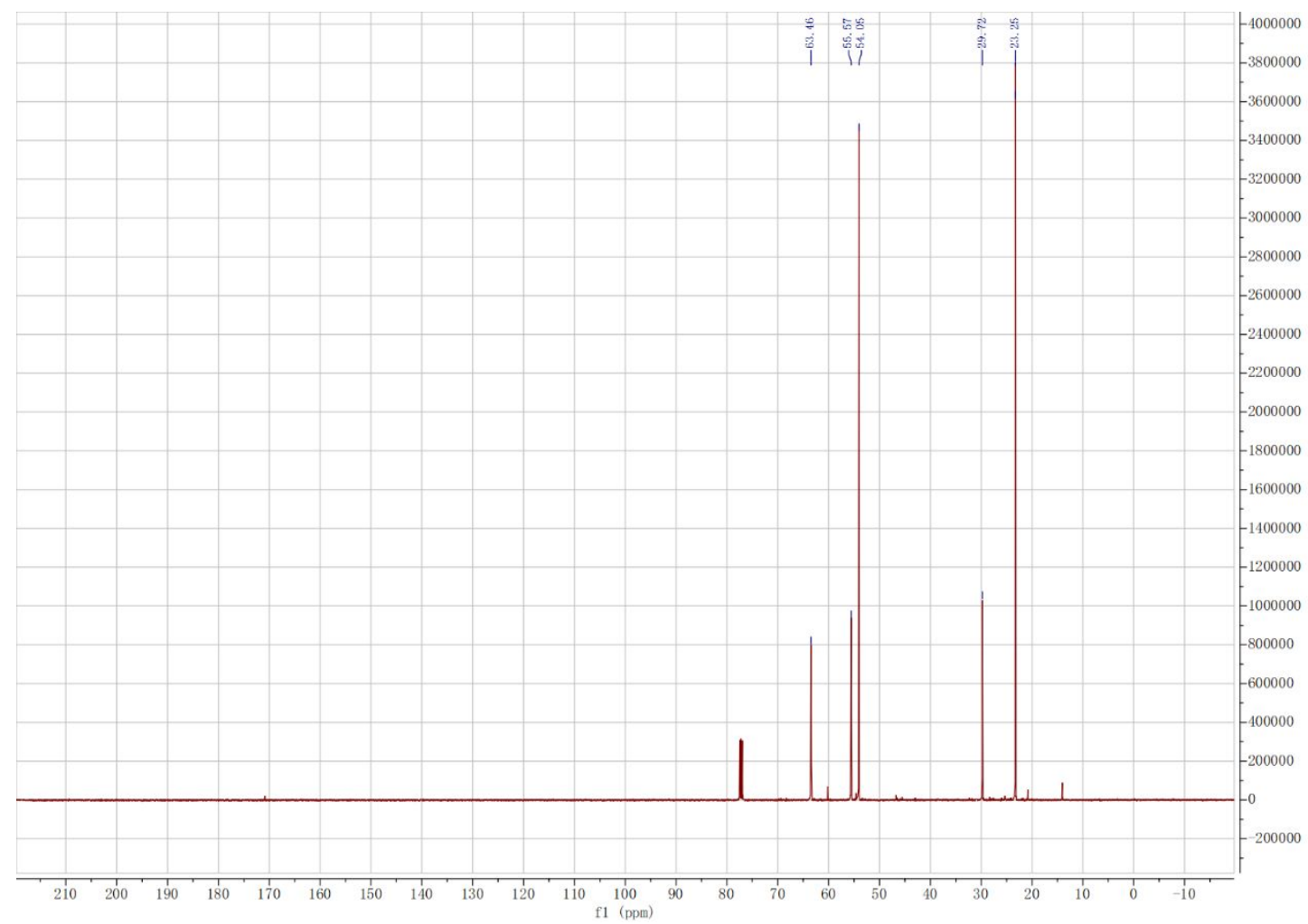

Figure S10. ${ }^{13} \mathrm{C}$ NMR of $\mathbf{S 8}$. 


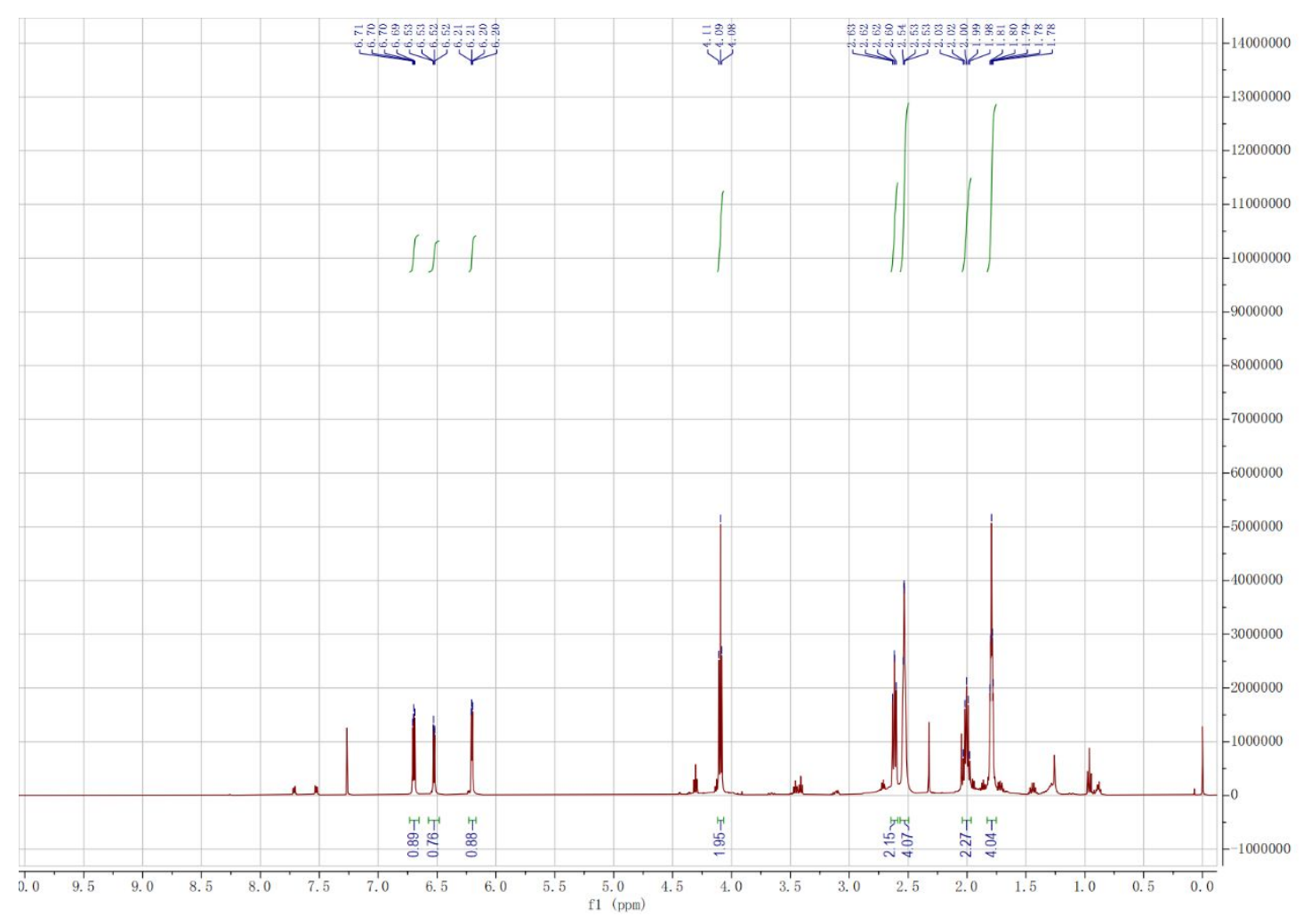

Figure S11. ${ }^{1} \mathrm{H}$ NMR of S9.

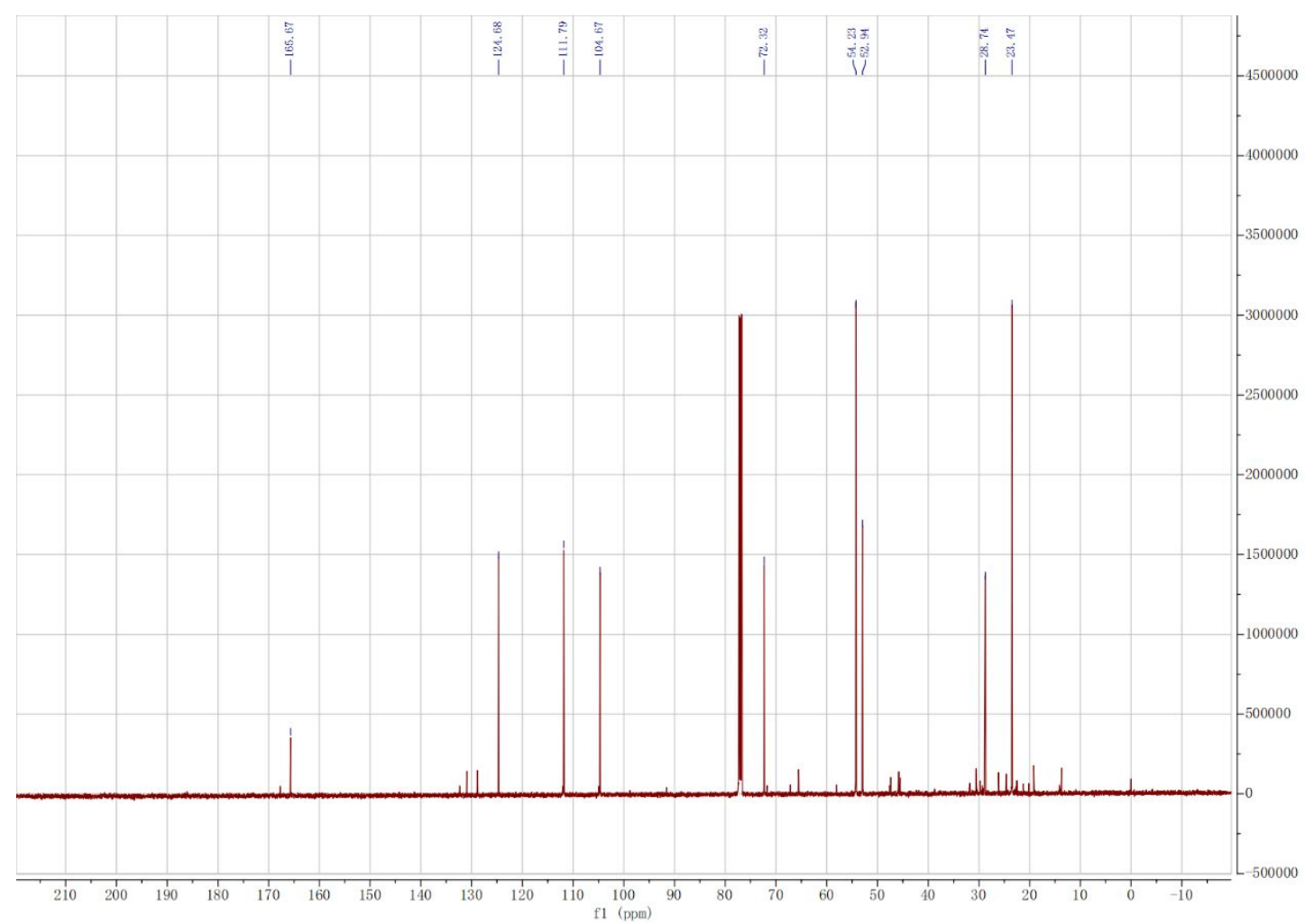

Figure S12. ${ }^{13} \mathrm{C}$ NMR of S9. 


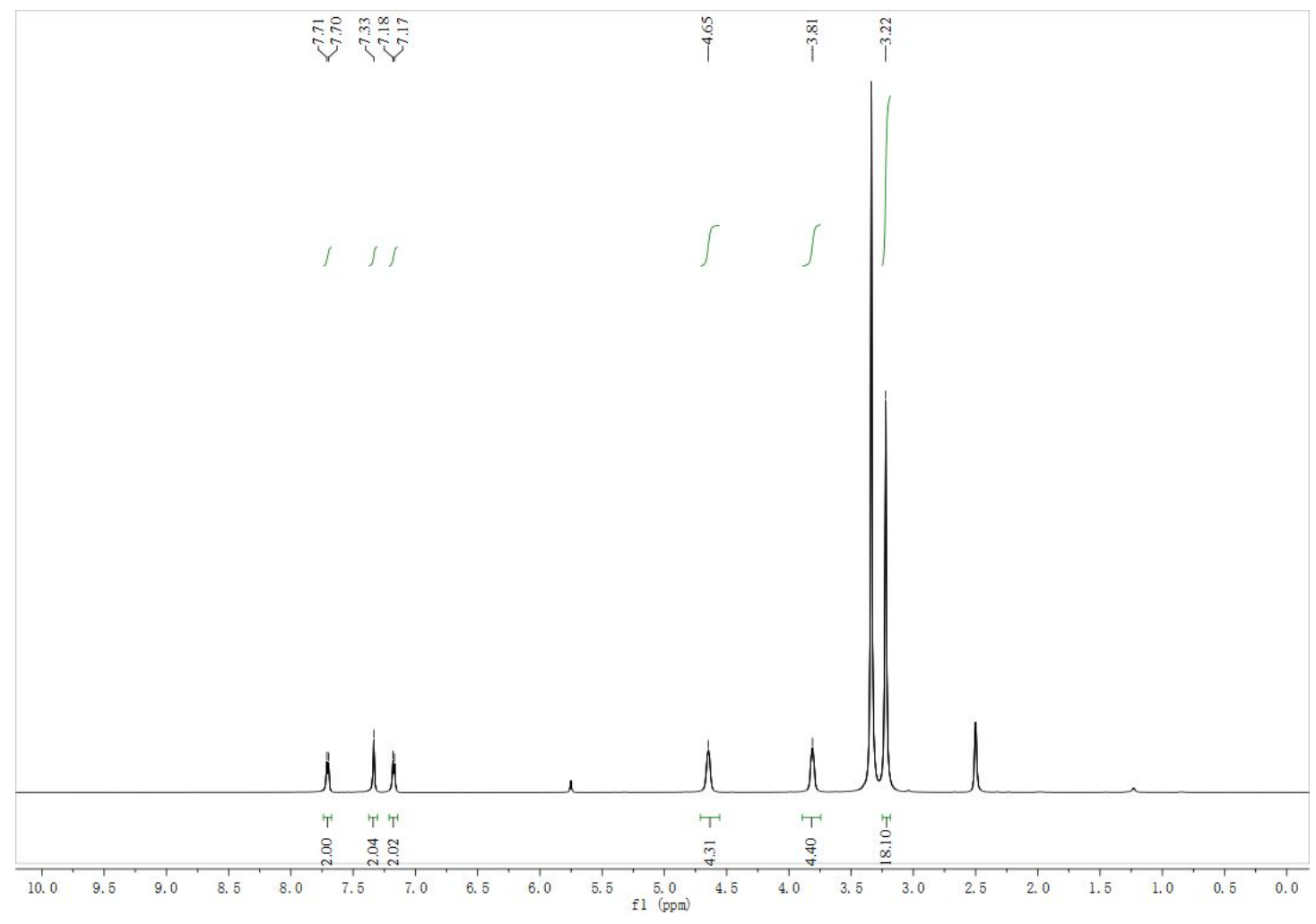

Figure S13. ${ }^{1} \mathrm{H}$ NMR of OTE-2.

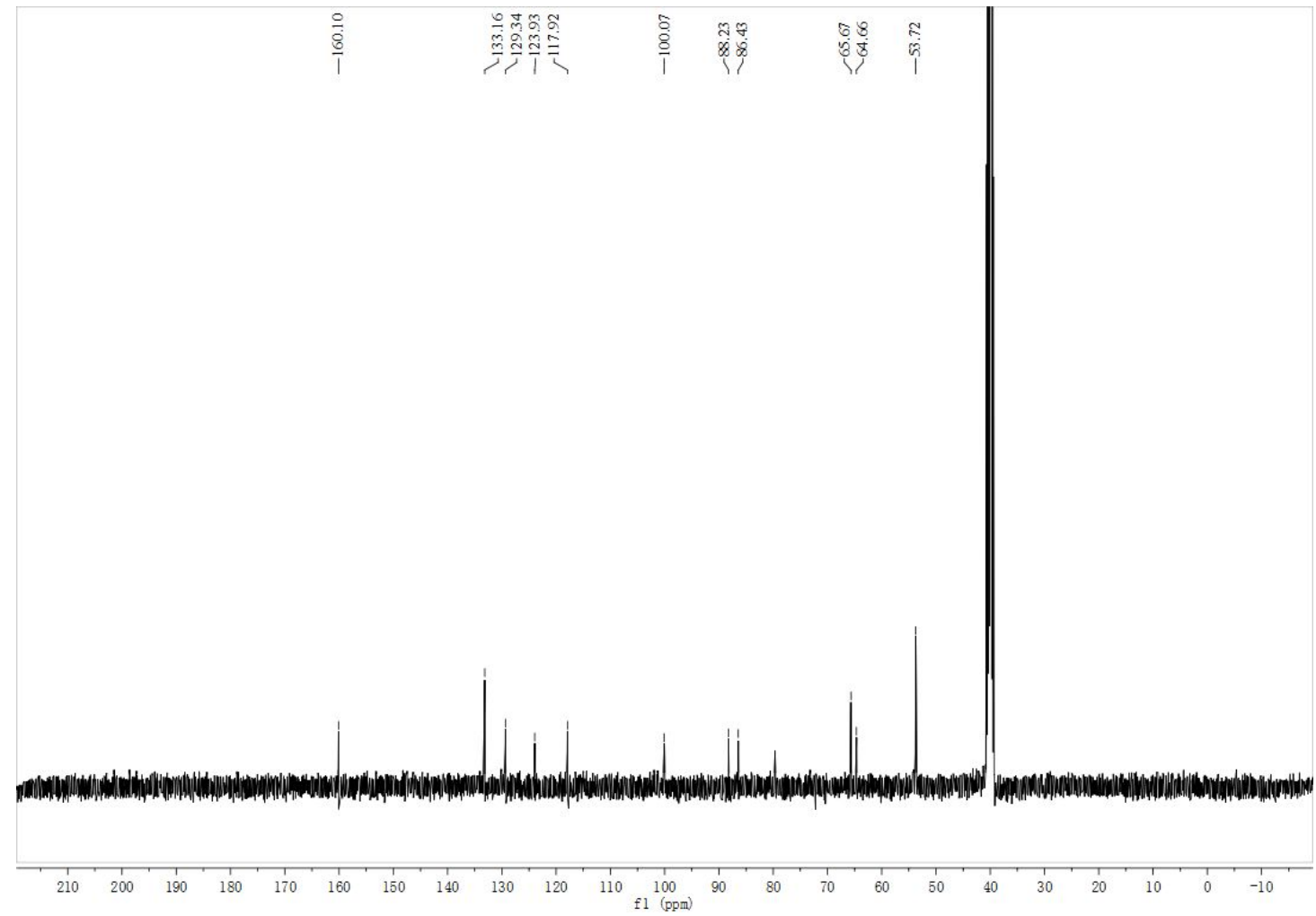

Figure S14. ${ }^{13} \mathrm{C}$ NMR of OTE-2. 


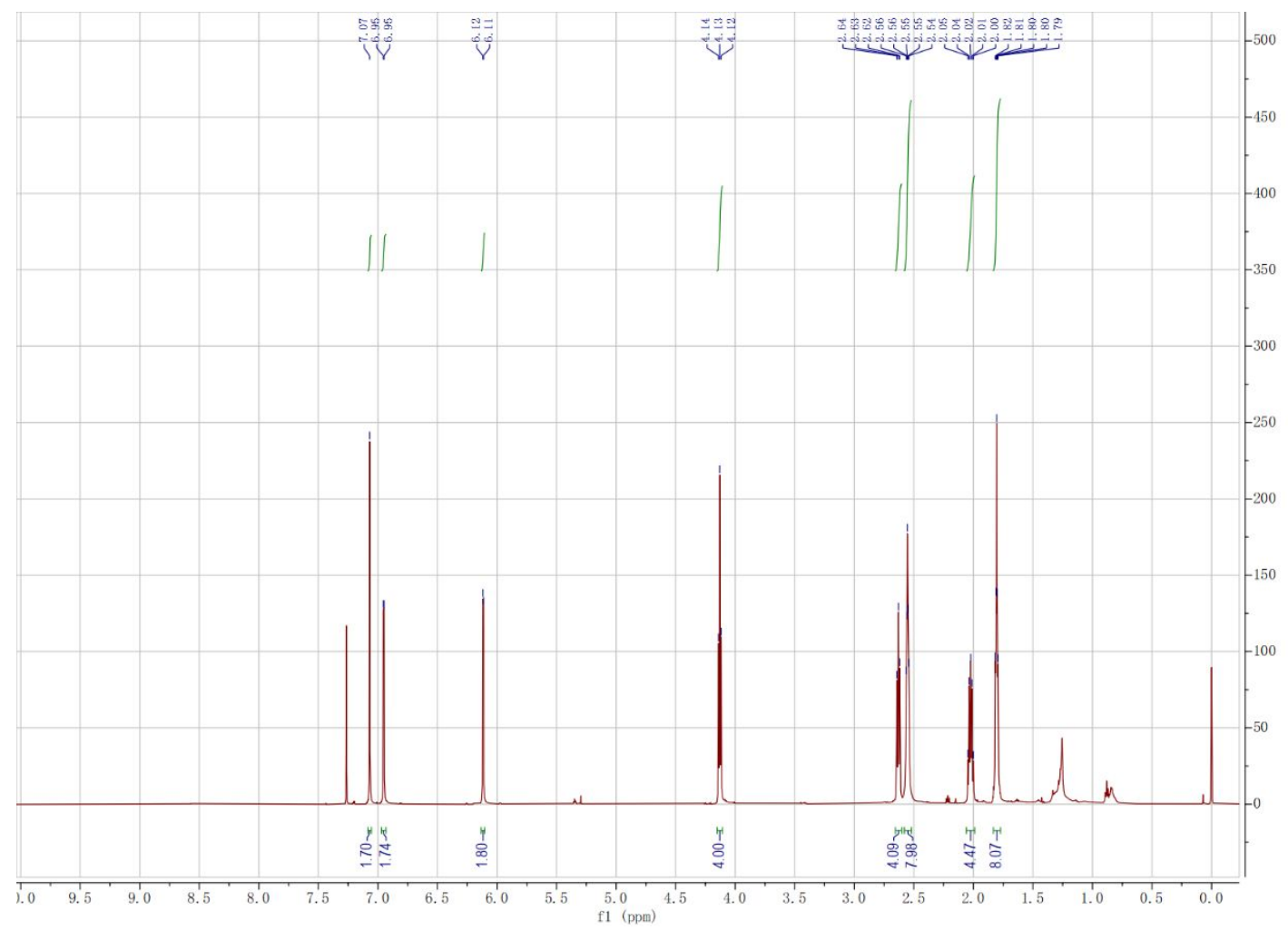

Figure S15. ${ }^{1} \mathrm{H}$ NMR of OTE-3.

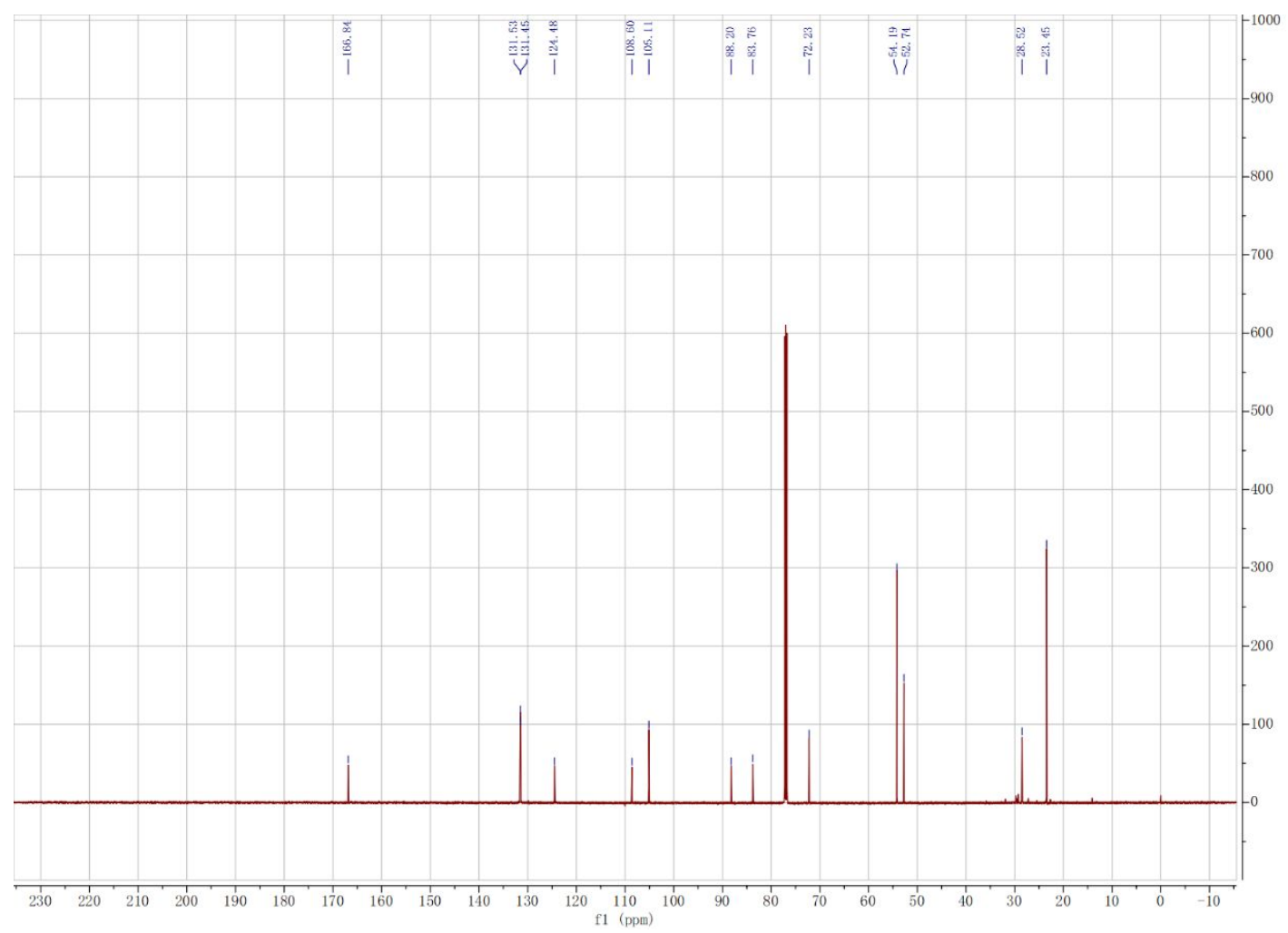

Figure S16. ${ }^{13} \mathrm{C}$ NMR of OTE-3. 


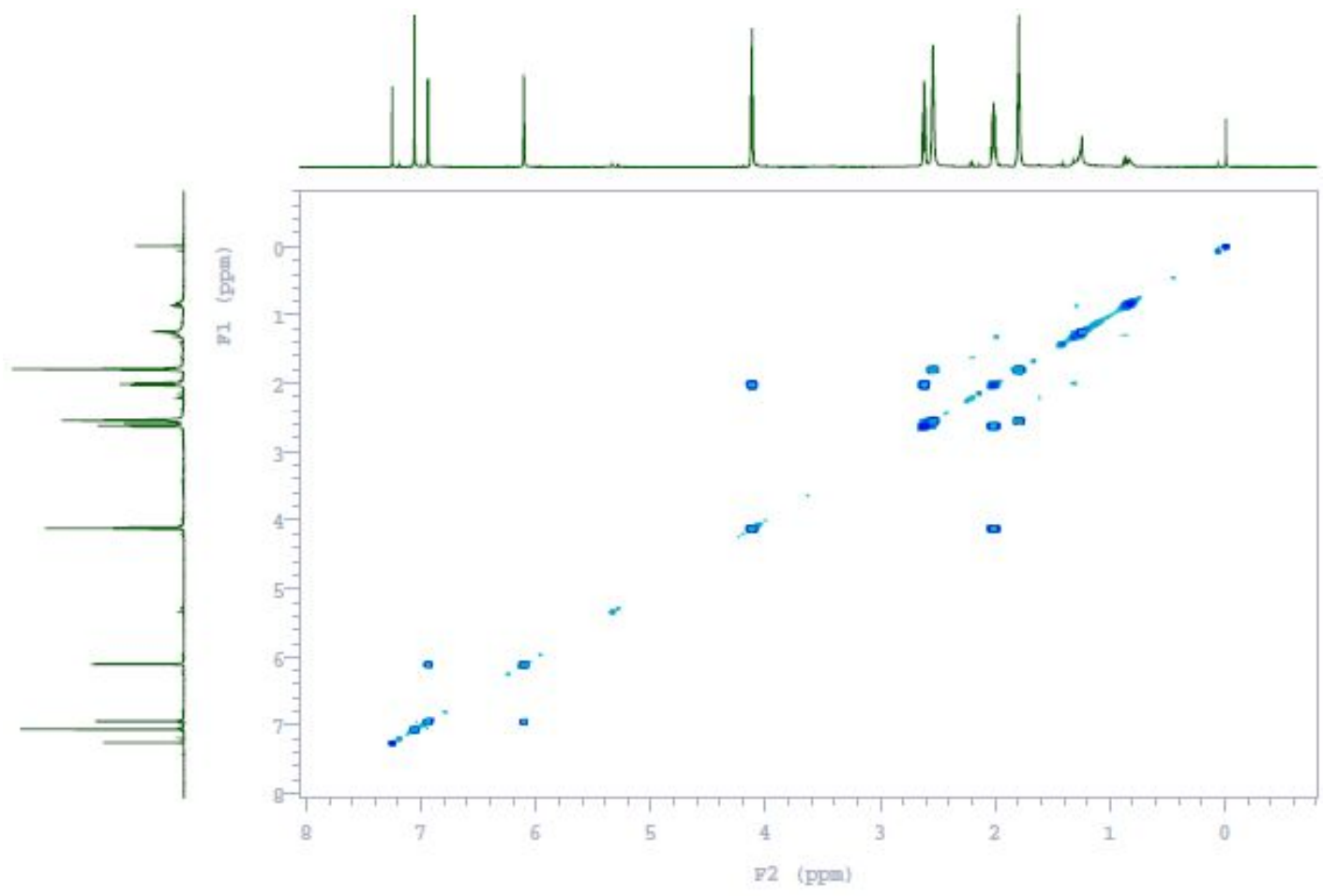

Figure S17. ${ }^{1} \mathrm{H}-{ }^{1} \mathrm{H}$ COSY of OTE-3.

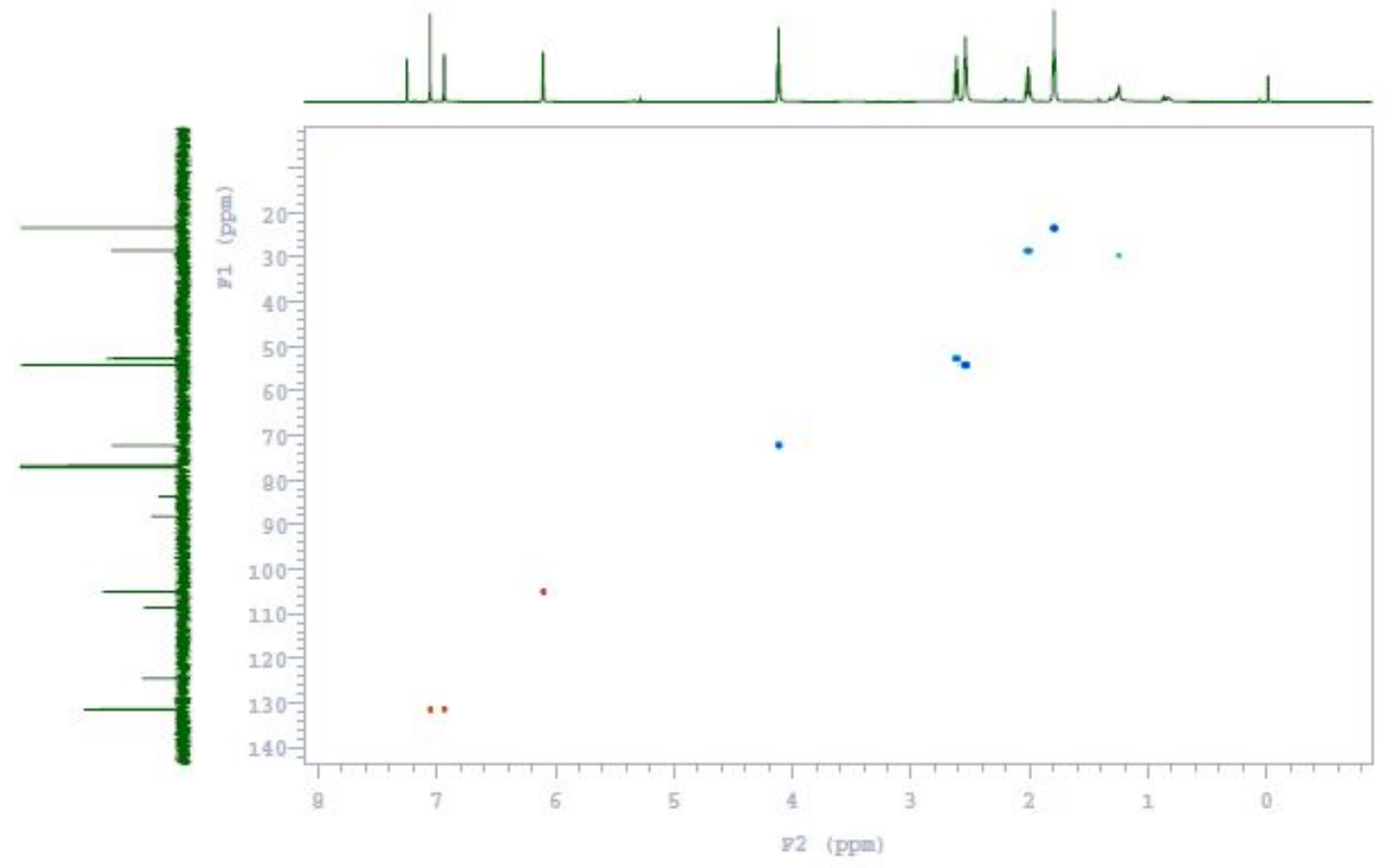

Figure S18. ${ }^{1} \mathrm{H}-{ }^{13} \mathrm{C}$ HSQC of OTE-3. 


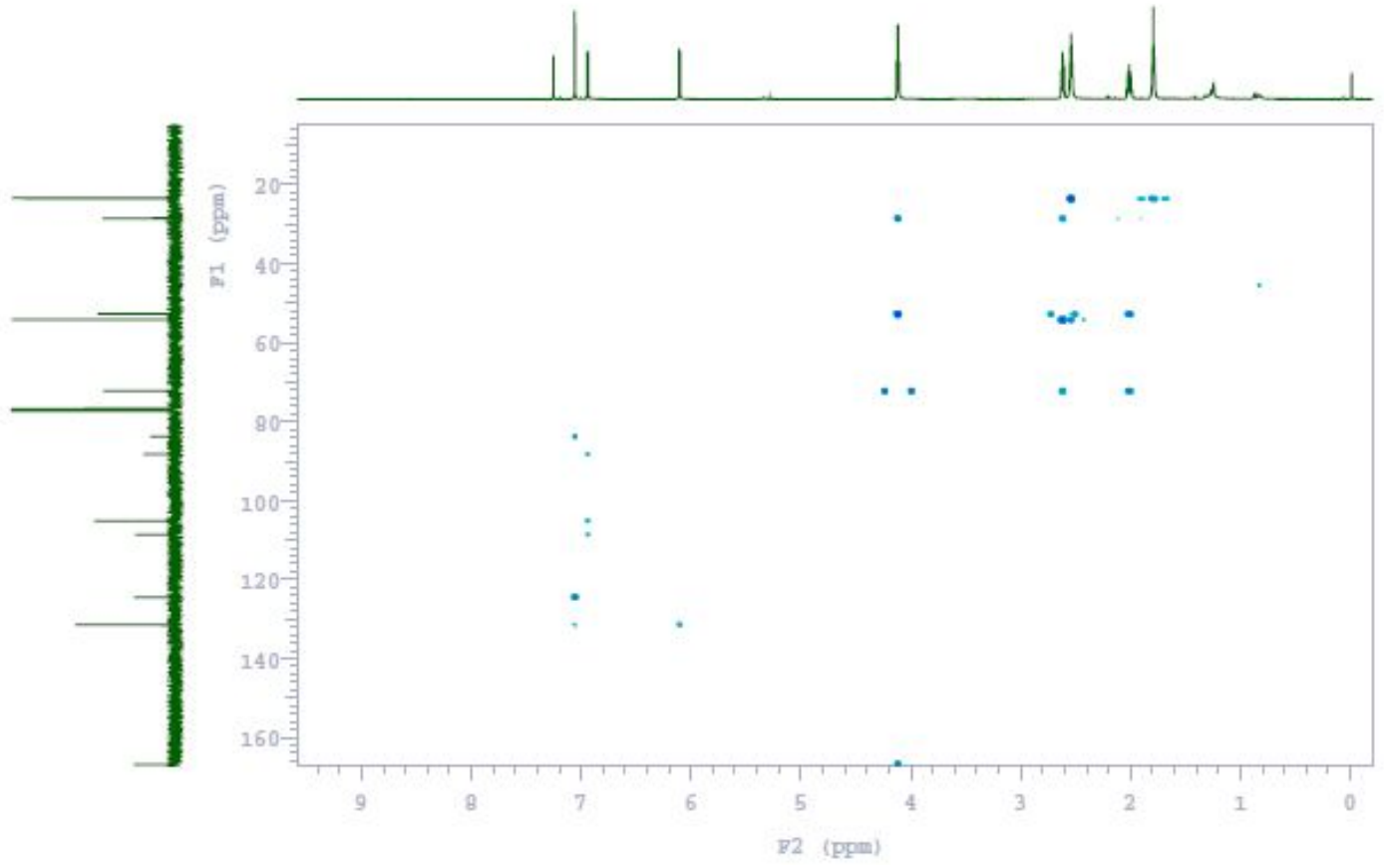

Figure S19. ${ }^{1} \mathrm{H}-{ }^{13} \mathrm{C}$ HMBC of OTE-3.

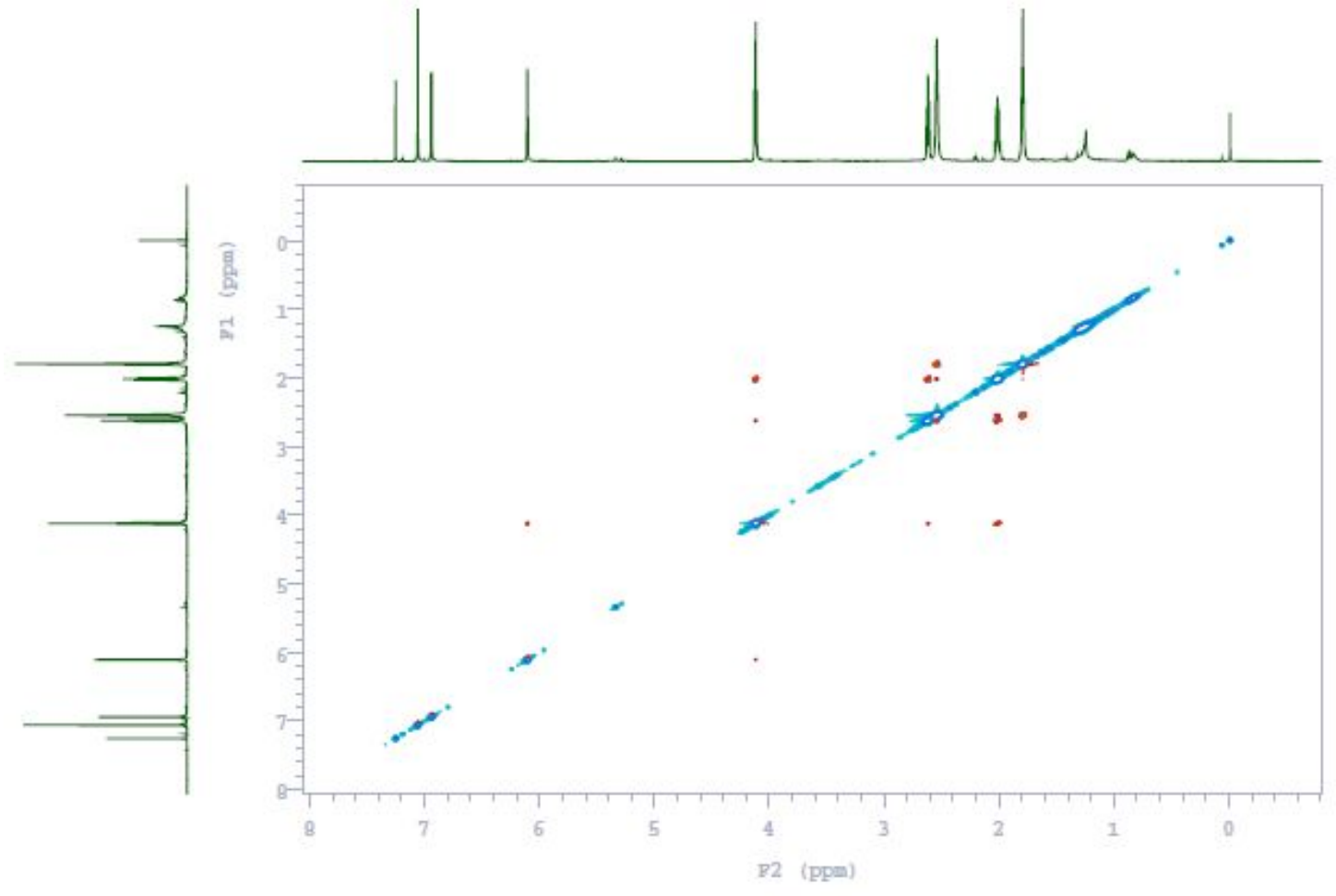




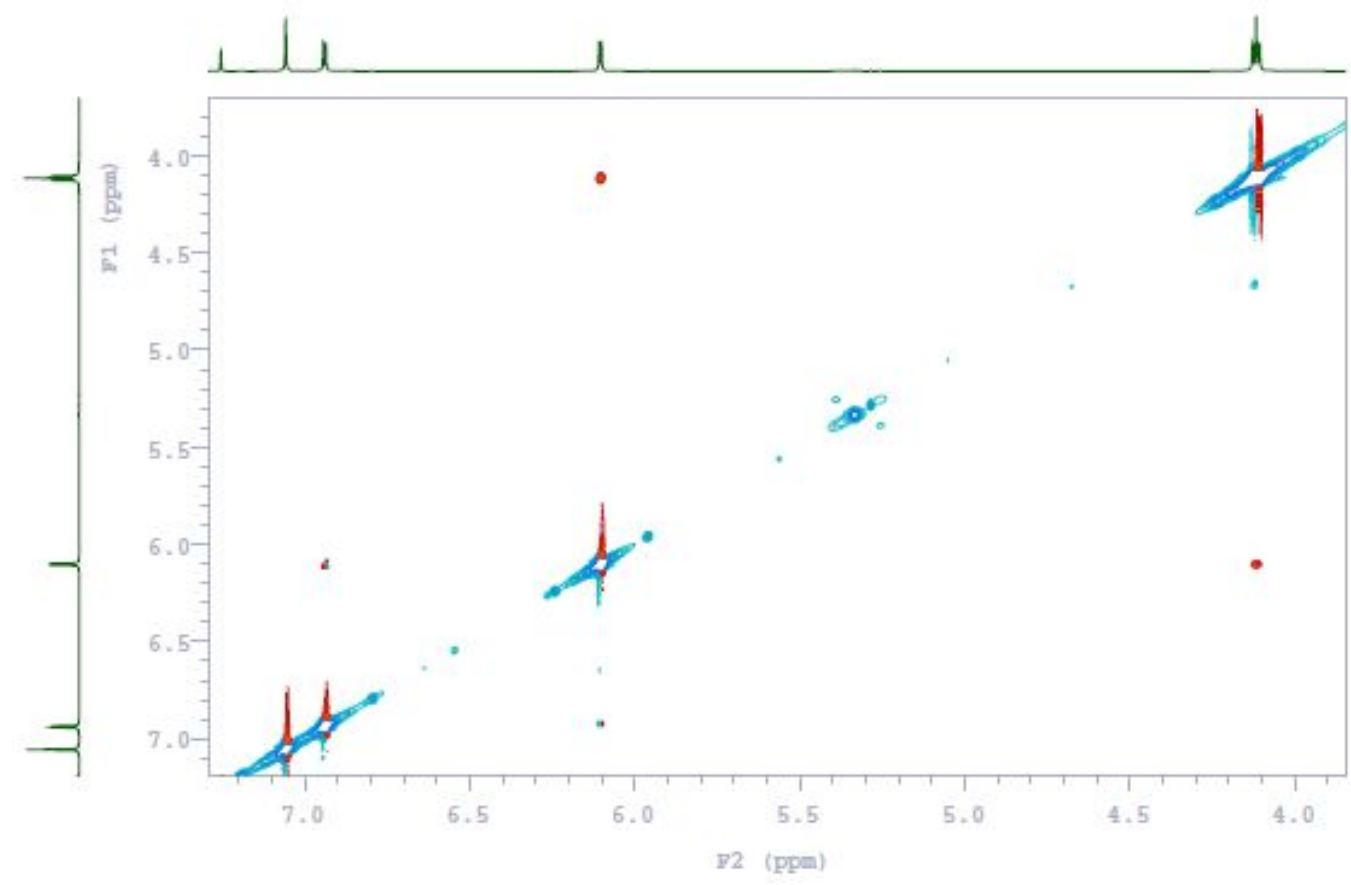

Figure S20 ${ }^{1} \mathrm{H}-{ }^{1} \mathrm{H}$ NOESY of OTE-3 (full and part spetra).

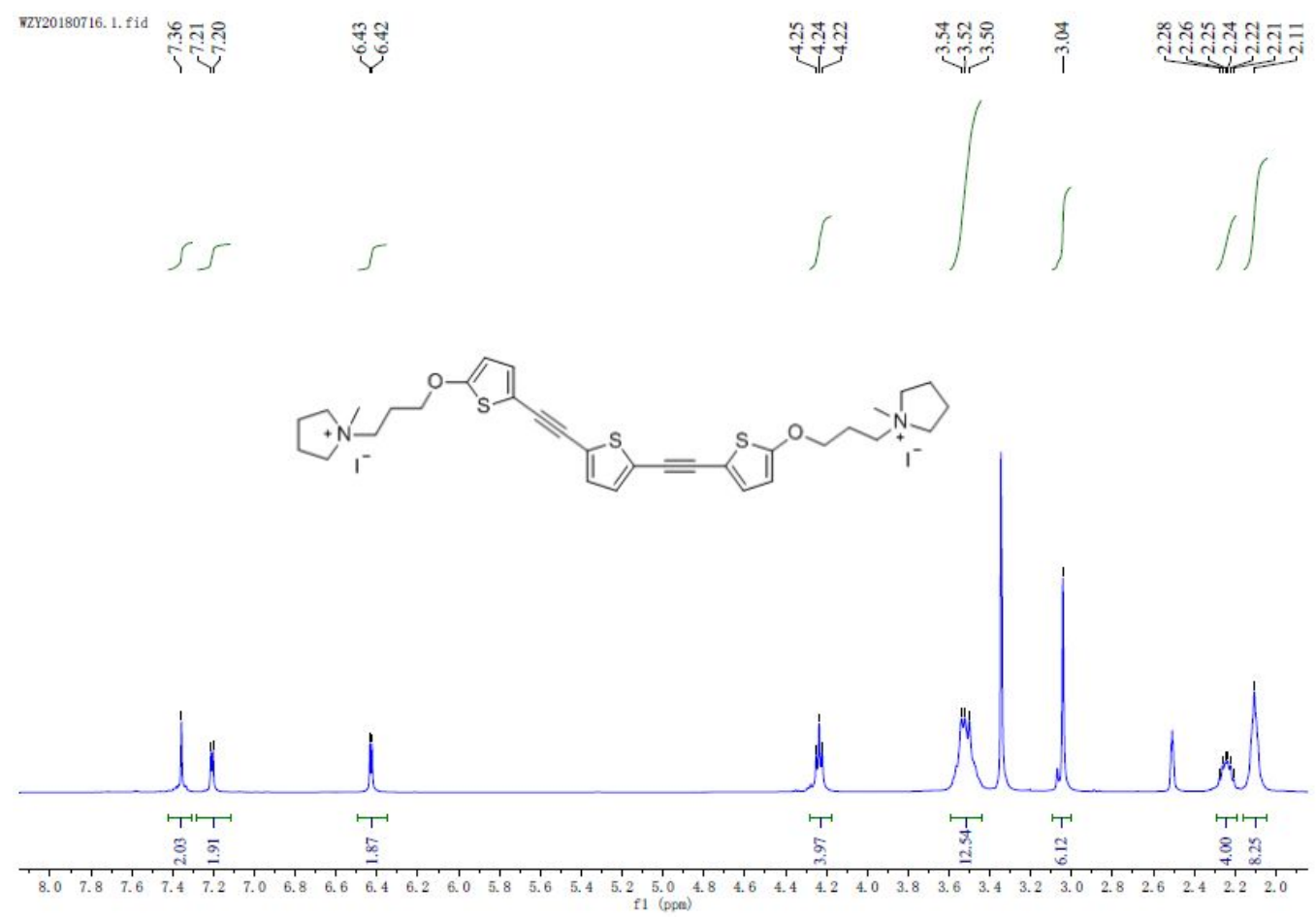

Figure S21. ${ }^{1} \mathrm{H}$ NMR of OTE-4. 


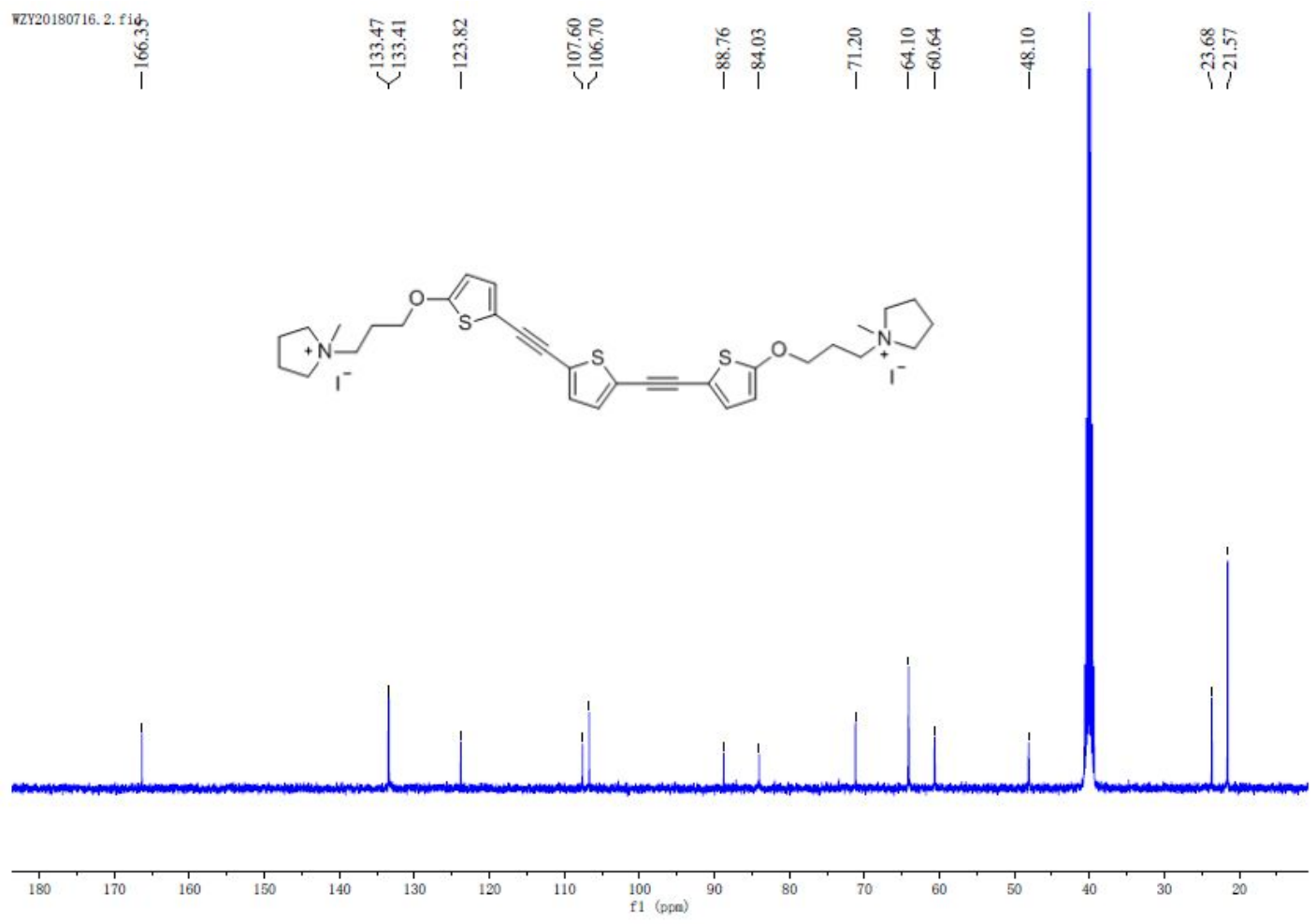

Figure S22. ${ }^{13} \mathrm{C}$ NMR of OTE-4. 


\subsection{Bacterial Growth Conditions}

Gram-positive bacterium $S$. aureus and Gram-negative bacterium E. coli were chosen for this study. Bacterial samples were transferred from the frozen the states to the agar slants (1.5\% agar and standard Luria broth) for both S. aureus and E. coli and incubated at $37{ }^{\circ} \mathrm{C}$ for $18 \mathrm{~h}$ and then held at $4{ }^{\circ} \mathrm{C}$ for up to 2 weeks. A single colony from the slants was incubated in $25 \mathrm{~mL} \mathrm{LB}$ and grown at $30{ }^{\circ} \mathrm{C}$ for $18 \mathrm{~h}$ with shaking. After growth, the bacterial culture was centrifuged at $4000 \mathrm{rpm}$ for 5 minutes. The pellet was resuspended in $25 \mathrm{~mL} 0.9 \% \mathrm{NaCl}$ solution after removing the $\mathrm{LB}$ and centrifuged. The washing procedure was repeated twice. The cell pellet was resuspended in $0.9 \% \mathrm{NaCl}$ solution and $\mathrm{OD}_{600}$ was adjusted to 1.0. The cell suspension was diluted 100 times by $0.9 \% \mathrm{NaCl}$ and final concentration of bacteria was about $10^{7} \mathrm{CFU} / \mathrm{mL}$.

\subsection{Bacterial Killing Experiments Uusing Flow Cytometry}

To test the antibacterial activities of OTE-1, OTE-2, OTE-3 and OTE-4, Gram-negative bacteria $E$. coli and Gram-positive $S$. aureus were incubated at different concentration of OTEs as follows: $0.1,0.3$ and $0.9 \mu \mathrm{g} / \mathrm{mL}$ for OTE-1 and OTE-2 against Gram-negative bacteria E. coli, 1.0, 3.0, $9.0 \mu \mathrm{g} / \mathrm{mL}$ for OTE-3 and OTE-4 against Gram-negative bacteria E. coli. and 33, 100 and $300 \mathrm{ng} / \mathrm{mL}$ for OTE-1, OTE-2, OTE-3 and OTE-4 against Gram-positive S. aureus under light irradiation $\left(5 \mathrm{~mW} / \mathrm{cm}^{2}\right)$ for 30 or 60 minutes. The concentration of all OTEs are 1.0, 3.0, $9.0 \mu \mathrm{g} / \mathrm{mL}$ under dark condition for E. coli and S. aureus. After the bacteria was incubated with the OTEs for 30 or $60 \mathrm{~min}$, the suspension was added a mixed dyes and kept in the dark for 15 minutes. The stains for Gram-negative bacteria E. coli are SYTO 9(green fluorescence) and propidium iodide (PI, red fluorescence). The stains for Gram-positive S. aureus are SYTO 24 (green fluorescence) and propidium iodide (PI, red fluorescence). The final concentration of SYTO 9, SYTO 24 and PI were 1.25 $\mu \mathrm{mol} / \mathrm{L}, 0.25 \mu \mathrm{mol} / \mathrm{L}$ and $7.5 \mu \mathrm{mol} / \mathrm{L}$, respectively. Finally, the stained bacteria were examined using flow cytometry. 


\subsection{Bacterial Killing Experiments Uusing Plate Counting}

The $\mathrm{OD}_{600}$ of bacterial suspension was adjusted to 1.0 and diluted 10 times by $0.9 \%$ $\mathrm{NaCl}$ and final concentration of bacteria was about $10^{8}$ cell $/ \mathrm{mL}$. Then the $S$. aureus or E. coli were incubated with OTEs at different concentrations. The used concentrations of OTEs against $S$. aureus are $300 \mathrm{ng} / \mathrm{mL}$ under light irradiation and $9 \mu \mathrm{g} / \mathrm{mL}$ under dark condition. The used concentrations of OTEs against E. coli are $0.9 \mu \mathrm{g} / \mathrm{mL}$ for OTE-1 and OTE-2 and $9 \mu \mathrm{g} / \mathrm{mL}$ for OTE-3 and OTE-4 under light irradiation and 9 $\mu \mathrm{g} / \mathrm{mL}$ under dark condition. The volume of bacterial suspension in each tube is 0.8 $\mathrm{mL}$ and tubes without OTEs was prepared as control for E. Coli and S. aureus. The samples were exposed to light $\left(5 \mathrm{~mW} / \mathrm{cm}^{2}\right)$ or in the dark for $1 \mathrm{~h}$, and the reaction was stopped by diluting the bacterial suspension with $0.9 \% \mathrm{NaCl}$ ten times. Further dilution steps were conducted by transferring $100 \mu \mathrm{L}$ suspension to $900 \mu \mathrm{L} 0.9 \%$ $\mathrm{NaCl}$, and $100 \mu$ Lof each dilution step was spread on agar plates. After $20 \mathrm{~h}$ of incubation at $37{ }^{\circ} \mathrm{C}$, the plates were examined and the number of CFU was counted.

\subsection{Preparation of Fluorescein-Loaded Vesicles and Vesicle Leakage Assays}

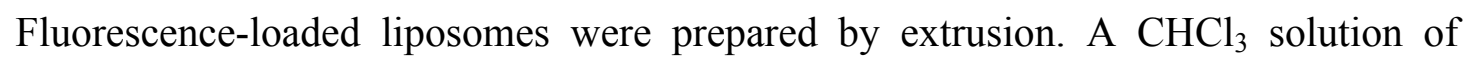
phospholipid was dried by rotary evaporator for 3 hours at $55{ }^{\circ} \mathrm{C}$. The dried lipid film was hydrated using $1 \mathrm{~mL} 100 \mathrm{mmol} / \mathrm{L}$ fluorescence solution of PBS buffer (adjusted to $\mathrm{pH} 7.4$ with $\mathrm{NaOH}$ ) with strong shaking for $10 \mathrm{~min}$ at temperature above the phase-transition temperature of the lipid. Then the liposomes were formed by extruding the lipid solution 23 times through a 200 -nm-pore-size polycarbonate membrane using a mini-extruder (Avanti Polar Lipids). Free fluorescence was

removed from the dye-loaded liposome by column filtration (Sephadex G-25 superfine) washing with PBS buffer. The hydrodynamic diameter and net surface charge of the liposomes were tested by dynamic light scattering (DLS, Nano Series, Malvern Corporation).

The liposome was diluted to proper concentration to use. The maximum fluorescence intensity of the liposome is achieved by addition of 10\% Triton X100 to 
the sample.

The interaction of liposome membrane and the OTEs was evaluated by a dye leakage assay. OTE was added to the dye-loaded liposome with a final OTE concentration of $4.0 \mu \mathrm{g} / \mathrm{mL}$ and $1 \mu \mathrm{g} / \mathrm{mL}$ for $D O P G$ liposome and liposome (DOPG:DOPE = 1:4, mole ratio), respectively. The OTE perturbed the membrane and the dye is released. The released dye was detected by the microplate reader (Synergy H1 microplate reader, BioTek Instruments. InC., excitation at $485 \mathrm{~nm}$, recorded at $525 \mathrm{~nm}$ ) every five minutes. All experiments were carried out under dark condition.

Fluorescein leakage was calculated using the following equation:

$$
\text { fluorescein leakage percentage }=\frac{F-F_{0}}{F_{\max }-F_{0}}
$$

where $F$ is the fluorescence of the samples after the addition of OTE, $F_{0}$ is the fluorescence intensity upon the addition of OTE, $F_{\max }$ is the maximum fluorescence intensity of the sample, achieved by the addition of $2 \mu \mathrm{L} 10 \%$ Triton X100 solution to $200 \mu \mathrm{L}$ liposome, which caused the complete releases of the dye.

\subsection{Zeta Potential Measurement}

The bacteria suspension was centrifuged and resuspended in PBS buffer $(\mathrm{pH}=7.4)$ to $\mathrm{OD}_{600}=1$. The cell suspension was diluted 10 times by PBS buffer and the final concentration of bacteria was about $10^{8} \mathrm{CFU} / \mathrm{mL} .1 \mathrm{~mL}$ bacterial suspension were incubated with $40 \mu \mathrm{M}$ OTEs for $1 \mathrm{~h}$, and the bacterial suspension without OTEs as control group. The suspension was transferred to the Malvern disposable folded capillary cell directly to measure the zeta potential.

\subsection{Cell Association Investigations}

OTEs were added to the $500 \mu \mathrm{L}$ S. aureus suspension at $\mathrm{OD}_{600}=1$ and the final concentrations are $40 \mu \mathrm{M}$. Four tubes without $S$. aureus were prepared as control group. The suspensions were incubated for $1 \mathrm{~h}$ at $37^{\circ} \mathrm{C} .200 \mu \mathrm{L}$ supernatant was transferred to a clean well to detect the absorption after centrifugation. The procedure of $E$. coli. was the same as $S$. aureus. 


\subsection{Reactive oxygen species (ROS) measurements}

$1.0 \mathrm{~mL} 40 \mu \mathrm{M}$ activated DCFH solution was added OTEs with a final concentration $10 \mu \mathrm{M}$. The solution was irradiated for 5 min under white light (5 $\mathrm{mW} / \mathrm{cm}^{2}$ ). The fluorescence spectra were measured with the excitation wavelength of $488 \mathrm{~nm}$ and recorded wavelength of $525 \mathrm{~nm}$.

\subsection{Observation of Cell Morphology}

E coli. (about $\left.10^{8} \mathrm{CFU} / \mathrm{mL}\right)$ were exposed to OTEs $(9 \mu \mathrm{g} / \mathrm{mL})$ or the negative control (without OTE) and then examined by SEM (Supra55, Karl Zeiss). For SEM imaging, the samples were resuspended in $2.5 \%$ glutaraldehyde and incubated at room temperature overnight to preserve the interface between the cells and antimicrobial agents, followed by washing with PBS buffer. Fixed cells were dehydrated by sequential treatment with increasing concentrations of ethanol for 30 minutes. The dehydrated samples were dried at room temperature and sputter coated with $\sim 10 \mathrm{~nm}$ of gold and palladium under vacuum and subsequently analyzed by SEM.

\subsection{Cytotoxicity}

The cytotoxicity of OTEs against HL-7702 cells was evaluated by MTS assay. HL-7702 cells were seeded into a 96-well plate at a density of $3.0 \times 10^{4}$ cells per well in $100 \mu \mathrm{L}$ of 1640 nutrient solution for $24 \mathrm{~h}$ at $37{ }^{\circ} \mathrm{C}$ in $5 \% \mathrm{CO}_{2}$. The OTEs was diluted with 1640 and added to the well $(100 \mu \mathrm{L})$, the final concentrations of each well are 9.0, 6.0, 3.0, 1.0, 0.1 and $0 \mu \mathrm{g} / \mathrm{mL}$, respectively. Then the cells were incubated for $24 \mathrm{~h}$ in the dark. Then, the cells were washed by PBS, and after removing the PBS, $100 \mu \mathrm{L} 1640$ with MTS was added into each well. The cells were incubated for a further $2 \mathrm{~h}$ and the optical density was read on a microplate reader at $490 \mathrm{~nm}$. 


\section{Supporting Figures and Table}

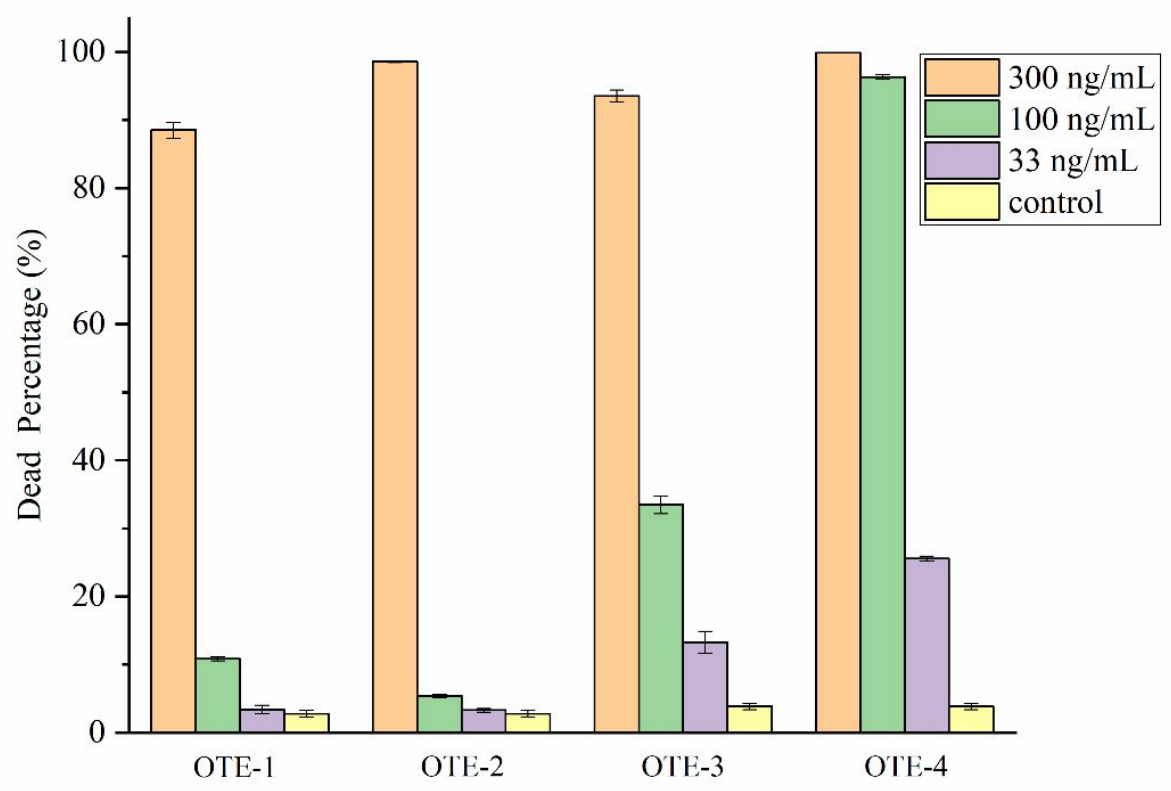

Figure S23. OTEs against $S$. aureus upon exposure to visible light $\left(5 \mathrm{~mW} / \mathrm{cm}^{2}\right)$ with the concentrations at $300,100,33$ and $0 \mathrm{ng} / \mathrm{mL}$ for $30 \mathrm{~min}$. The error bars represent the standard deviations of three parallel measurements.

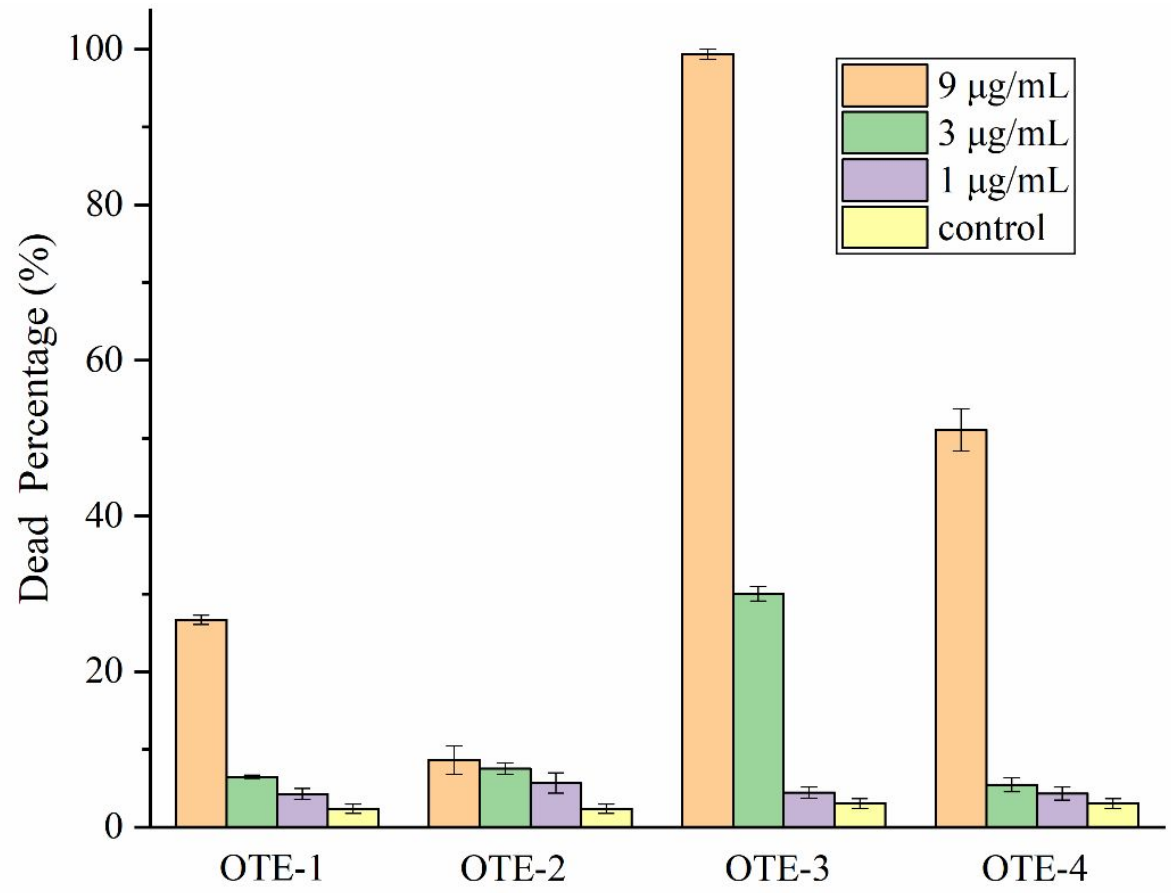

Figure S24. OTEs against $S$. aureus in the dark with the concentration at 9, 3, 1 and 0 $\mu \mathrm{g} / \mathrm{mL}$ for $30 \mathrm{~min}$. The error bars represent the standard deviations of three parallel 
measurements.

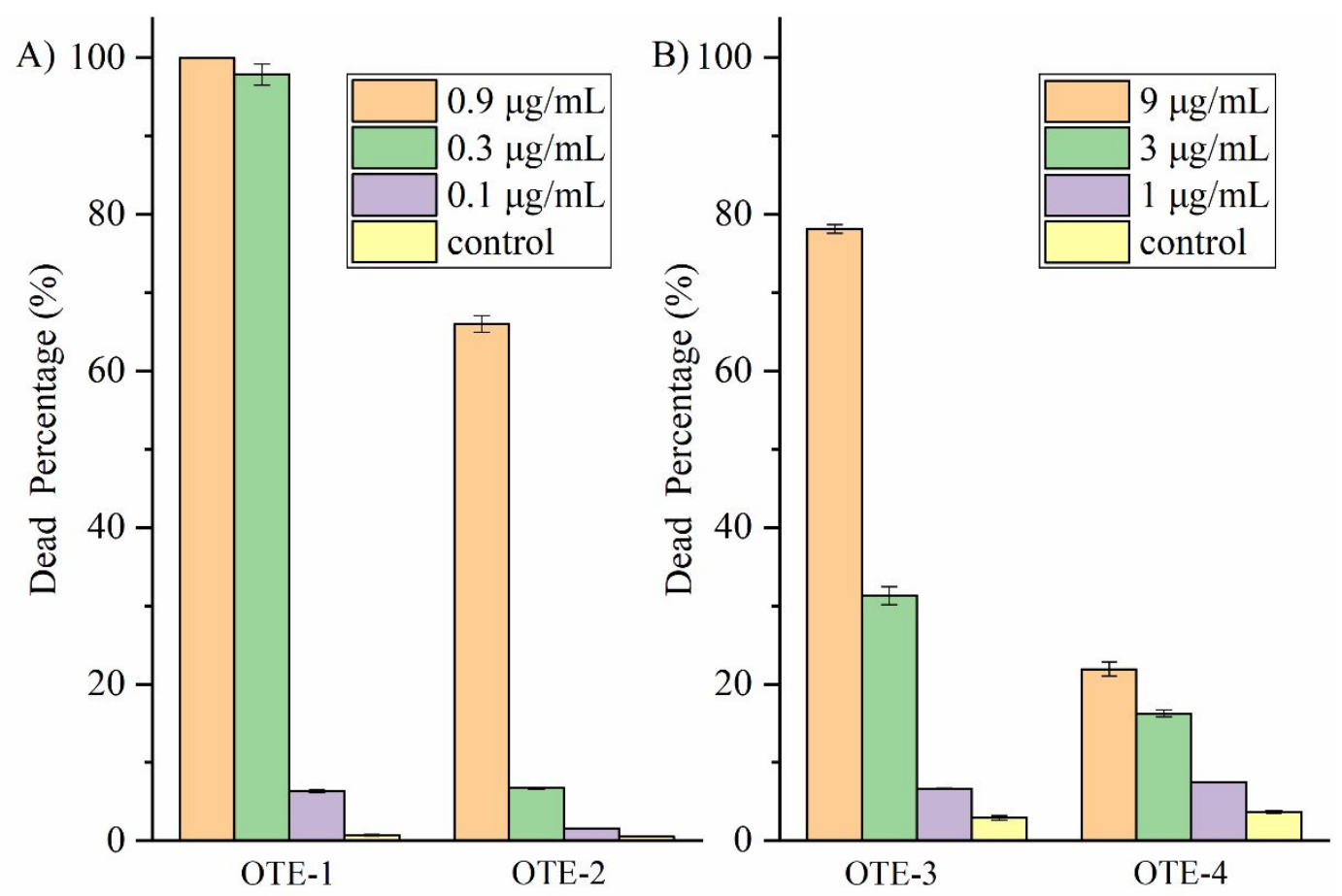

Figure S25. OTEs against $E$. coli upon exposure to visible light $\left(5 \mathrm{~mW} / \mathrm{cm}^{2}\right)$ with the concentrations at $0.9,0.3,0.1$ and $0 \mu \mathrm{g} / \mathrm{mL}$ for OTE-1, OTE-2, 9, 3, 1 and $0 \mu \mathrm{g} / \mathrm{mL}$ for OTE-3, OTE-4 for 30 min: a) OTE-1 and OTE-2; b) OTE-3 and OTE-4. The error bars represent the standard deviations of three parallel measurements. 


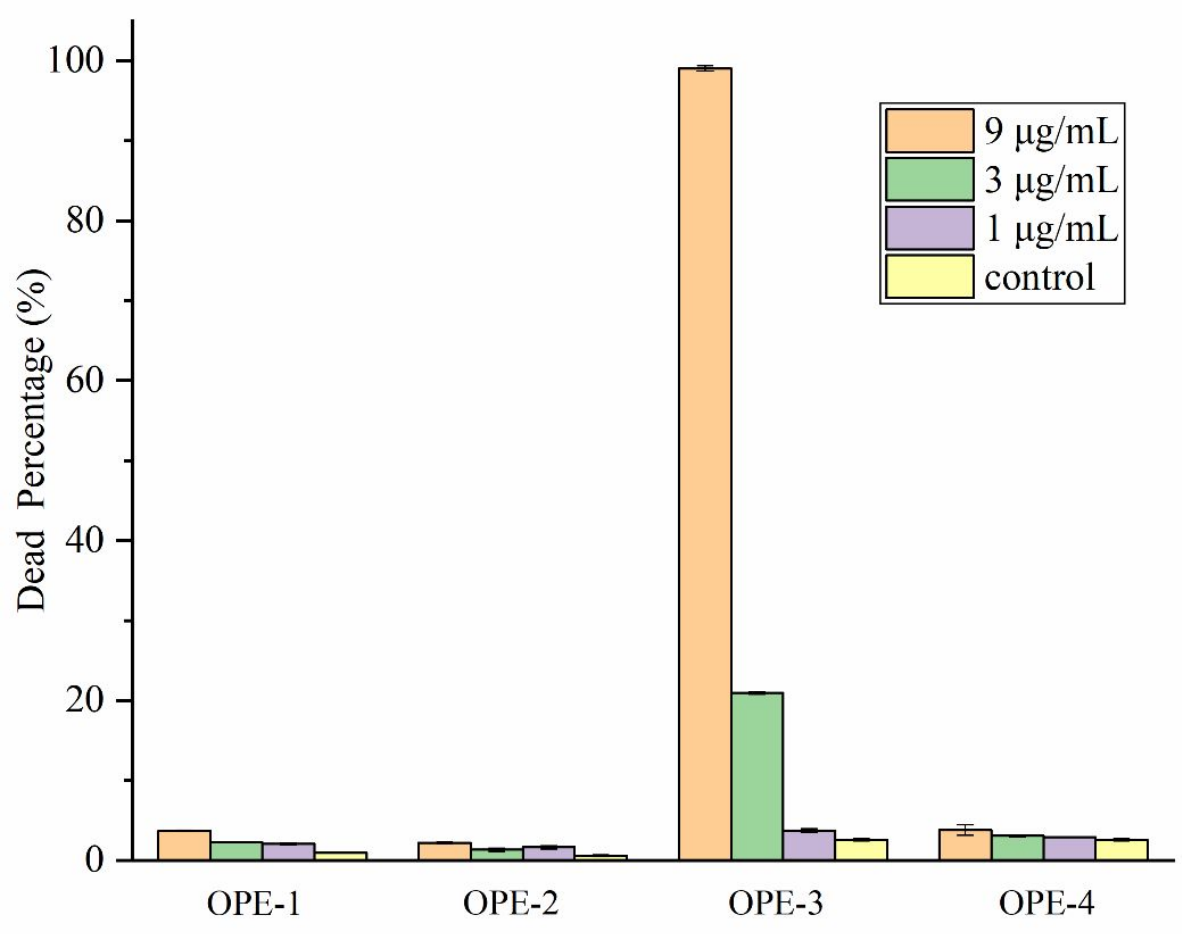

Figure S26. OTEs against $E$. coli upon in the dark with the concentrations at 9, 3, 1 and $0 \mu \mathrm{g} / \mathrm{mL}$ for $60 \mathrm{~min}$. The error bars represent the standard deviations of three parallel measurements.

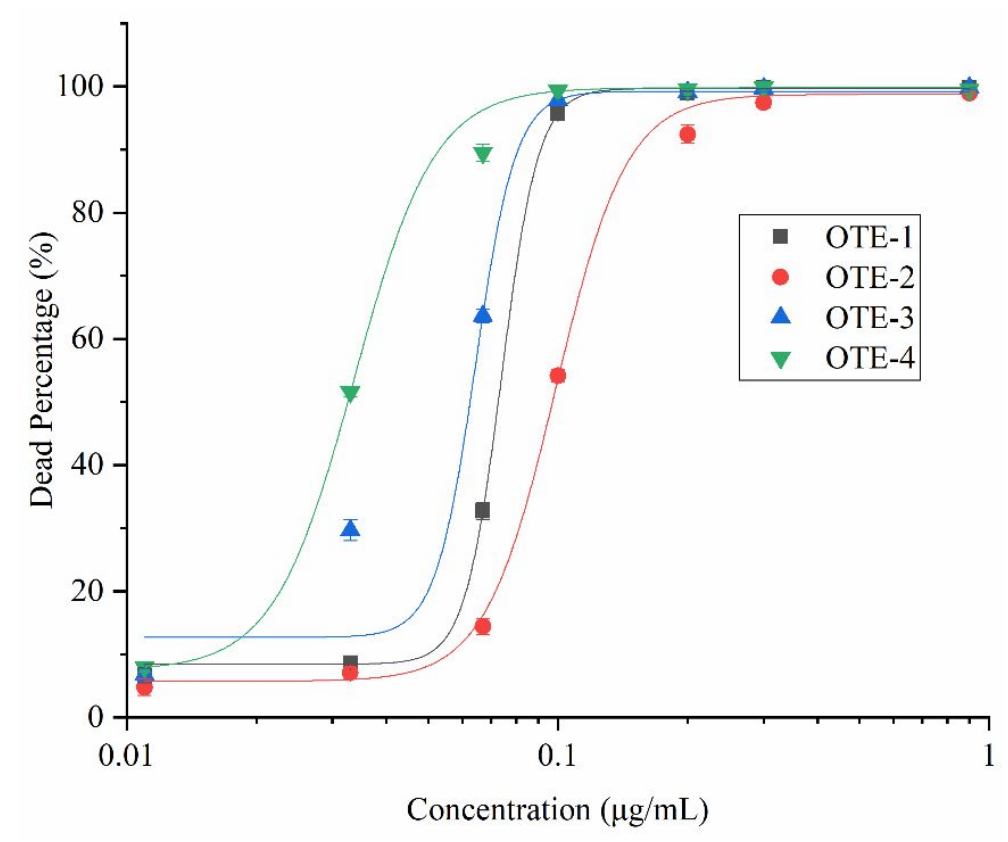

Figure S27. OTEs against $S$. aureus upon exposure to visible light $\left(5 \mathrm{~mW} / \mathrm{cm}^{2}\right)$ at various concentrations for $60 \mathrm{~min}$. The $\mathrm{IC}_{50}$ of OTE-1, OTE-2, OTE-3 and OTE-4 are $0.07,0.1,0.06$ and $0.03 \mu \mathrm{g} / \mathrm{mL}$, respectively. 


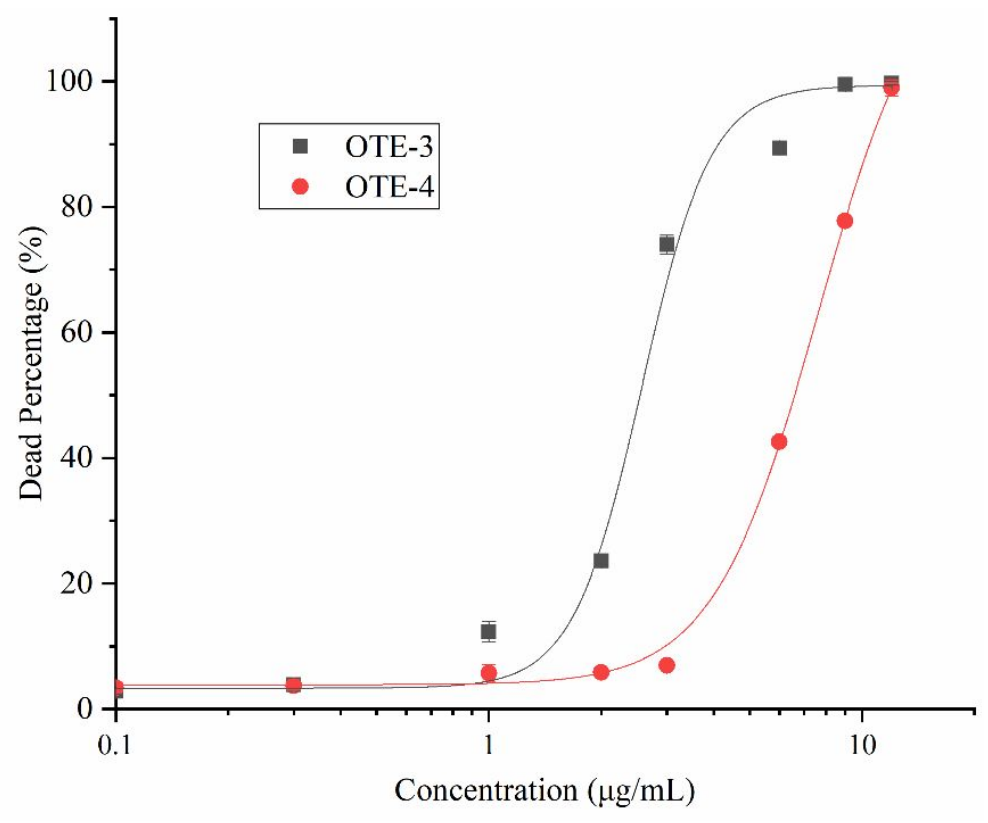

Figure S28. OTEs against $S$. aureus in the dark at various concentrations for $60 \mathrm{~min}$. The $\mathrm{IC}_{50}$ of OTE-3 and OTE-4 are 2.57 and $7.63 \mu \mathrm{g} / \mathrm{mL}$, respectively.

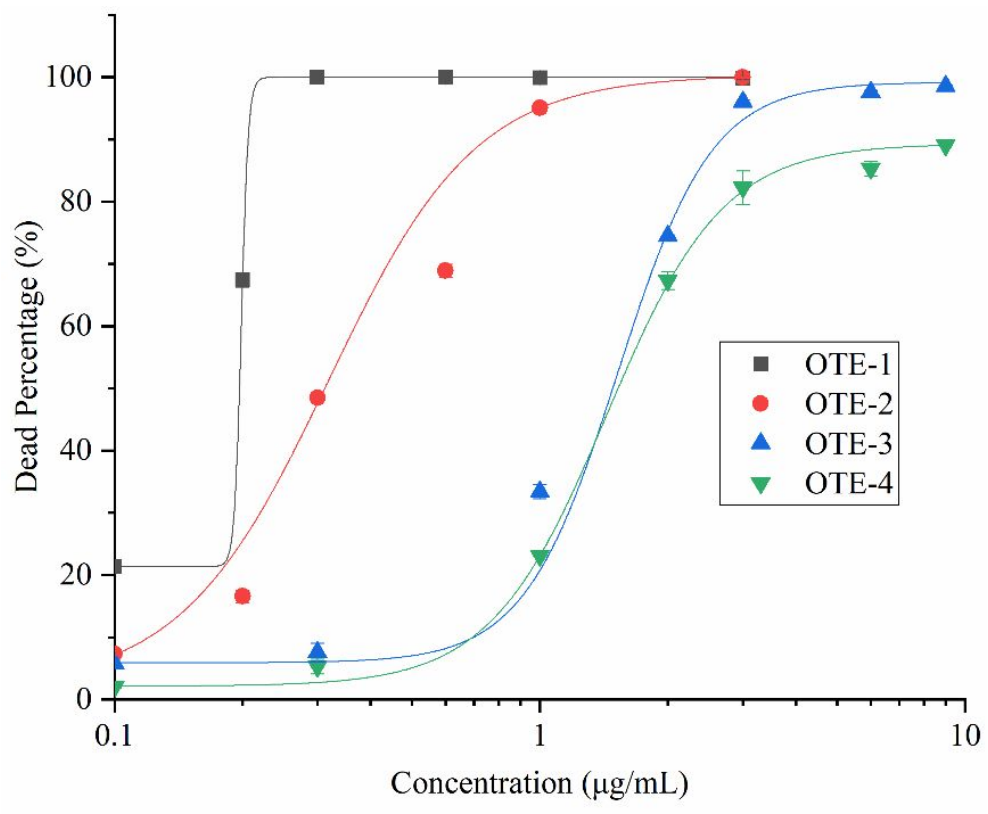

Figure S29. OTEs against $E$. coli upon exposure to visible light $\left(5 \mathrm{~mW} / \mathrm{cm}^{2}\right)$ at various concentrations for $60 \mathrm{~min}$. The $\mathrm{IC}_{50}$ of OTE-1, OTE-2, OTE-3 and OTE-4 are $0.2,0.32,1.53$ and $1.44 \mu \mathrm{g} / \mathrm{mL}$, respectively. 


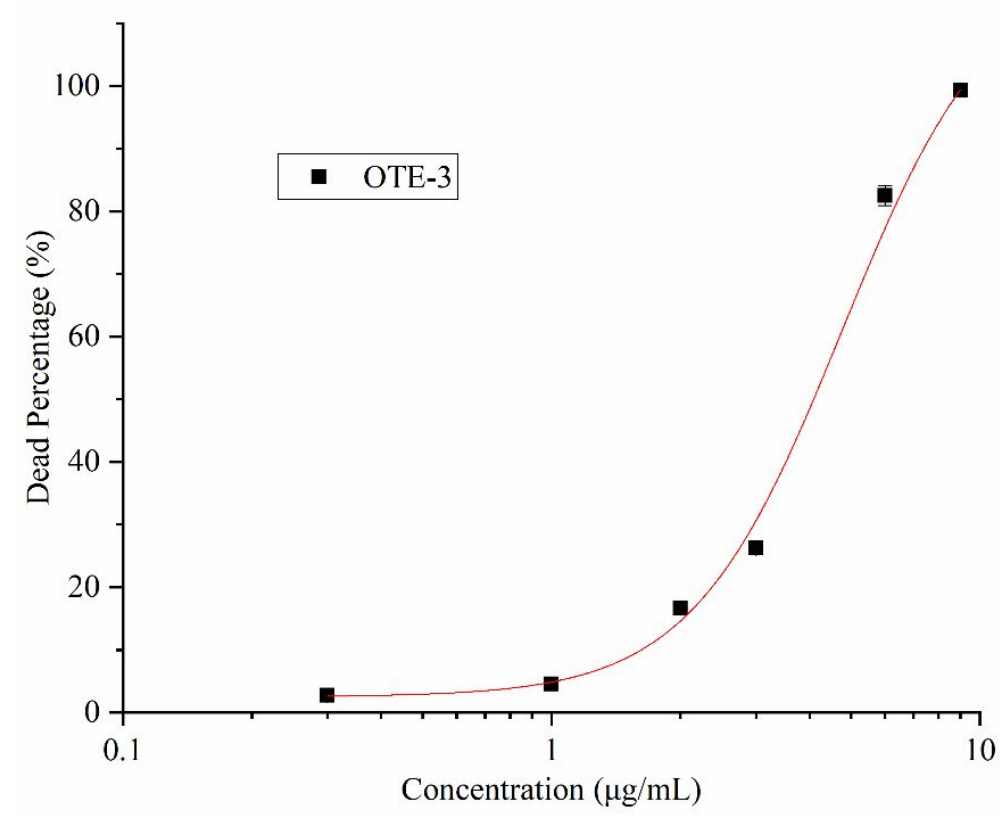

Figure S30. OTEs against E.coli in the dark at various concentrations for $60 \mathrm{~min}$. The $\mathrm{IC}_{50}$ of OTE-3 is $4.76 \mu \mathrm{g} / \mathrm{mL}$.

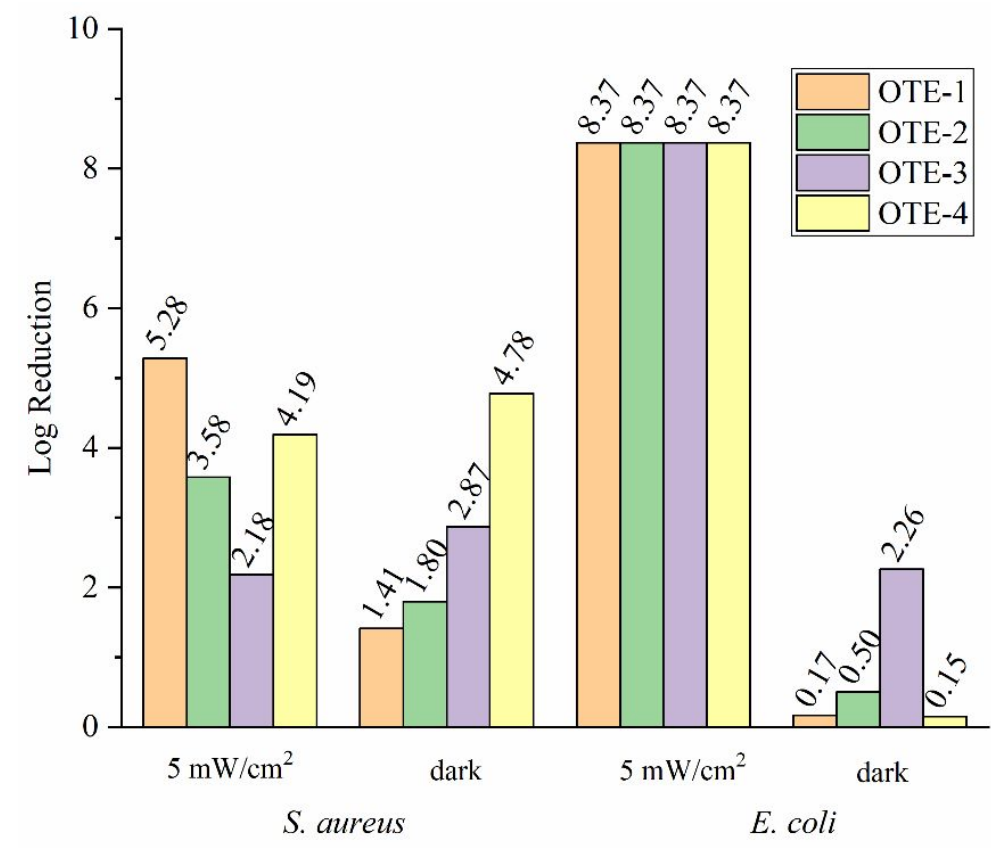

Figure S31. Log reduction of CFU/mL determined by plate counting for $1 \mathrm{~h}$ irradiation $\left(5 \mathrm{~mW} / \mathrm{cm}^{2}\right)$ and dark incubation with OTEs. The used concentrations of OTEs against $S$. aureus are $300 \mathrm{ng} / \mathrm{mL}$ under light irradiation and $9 \mu \mathrm{g} / \mathrm{mL}$ under dark condition. The used concentrations of OTEs against $E$. coli are $0.9 \mu \mathrm{g} / \mathrm{mL}$ for OTE-1 
and OTE-2 and $9 \mu \mathrm{g} / \mathrm{mL}$ for OTE-3 and OTE-4 under light irradiation and $9 \mu \mathrm{g} / \mathrm{mL}$ under dark condition.

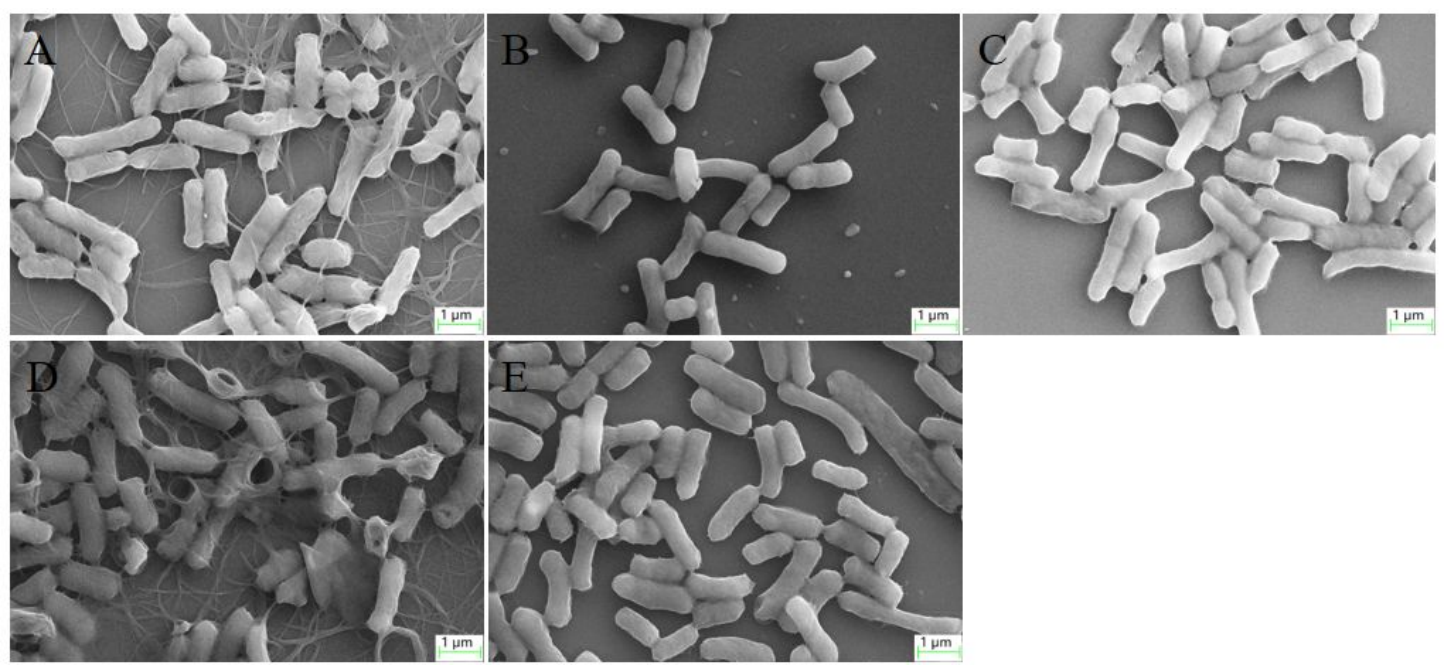

Figure S32. SEM images of $E$. coli cells (about $10^{8} \mathrm{CFU} / \mathrm{mL}$ ) incubated with OTE-1 (A) or OTE-2 (B) or OTE-3 (C) or OTE-4 (D) and E. coli cells alone (E) under dark condition for $60 \mathrm{~min}$. The concentrations of OTEs were $9 \mu \mathrm{g} / \mathrm{mL}$. Scale bars are $1 \mu \mathrm{m}$.

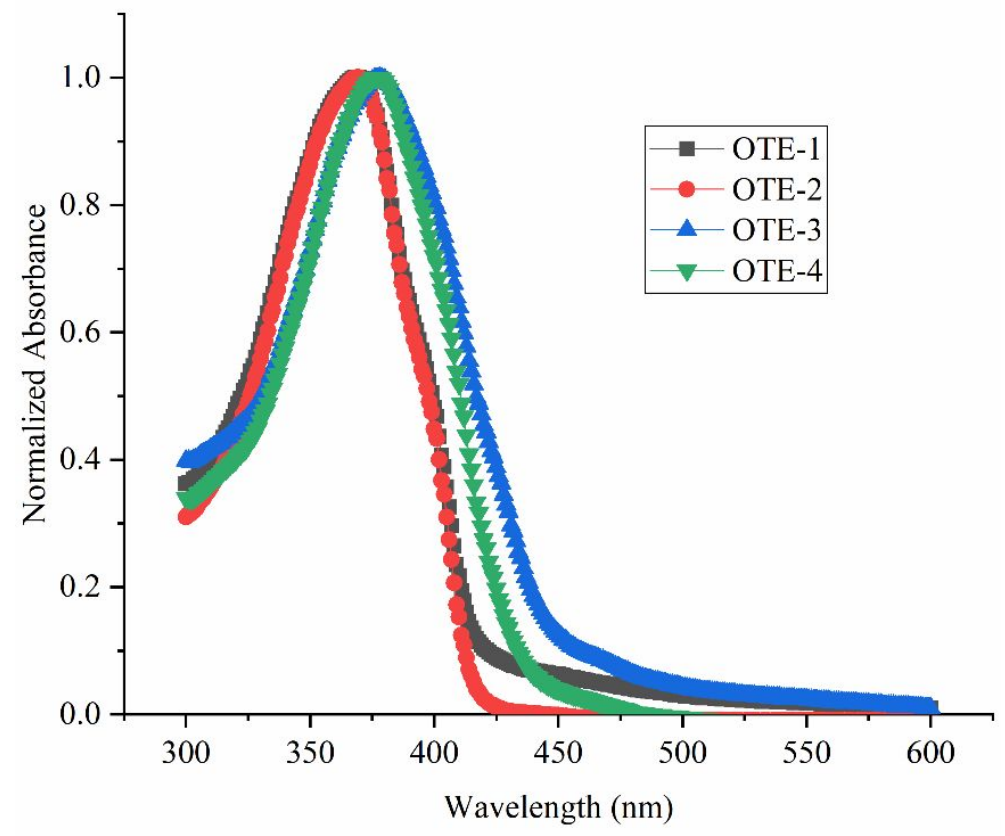

Figure S33. Absorption spectra of OTEs in water. 


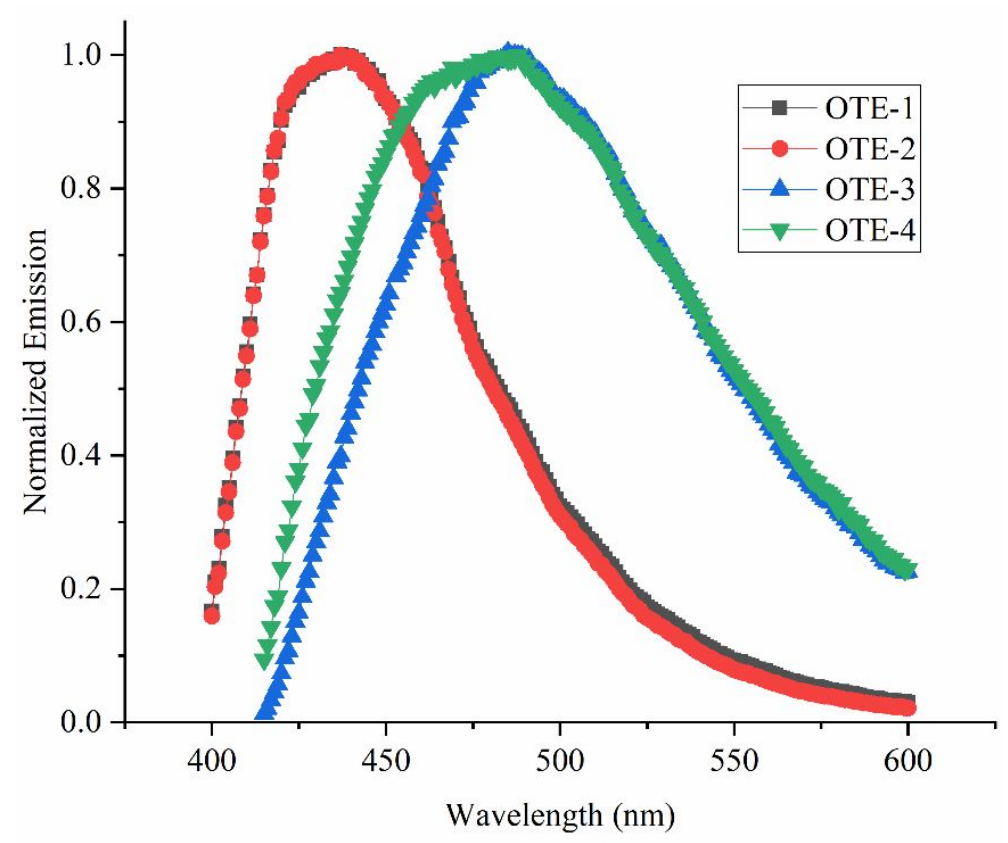

Figure S34. Fluorescence spectra of OTEs in water.

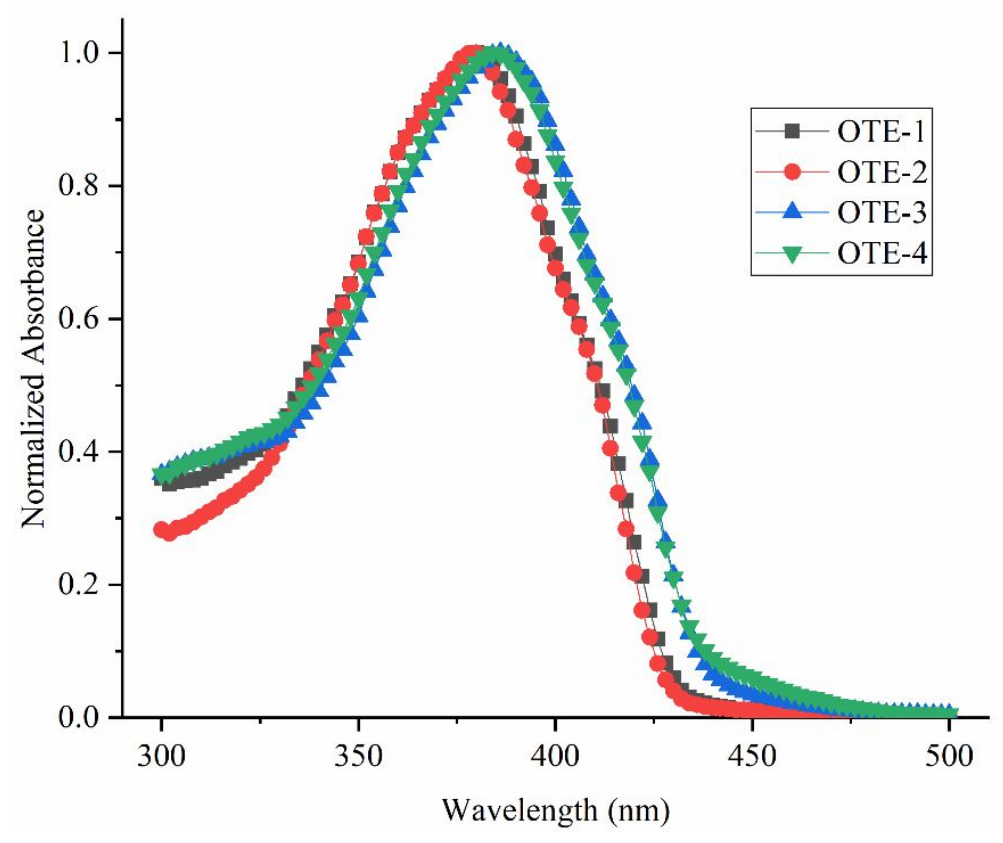

Figure S 35. Absorption spectra of OTEs in DMSO. 


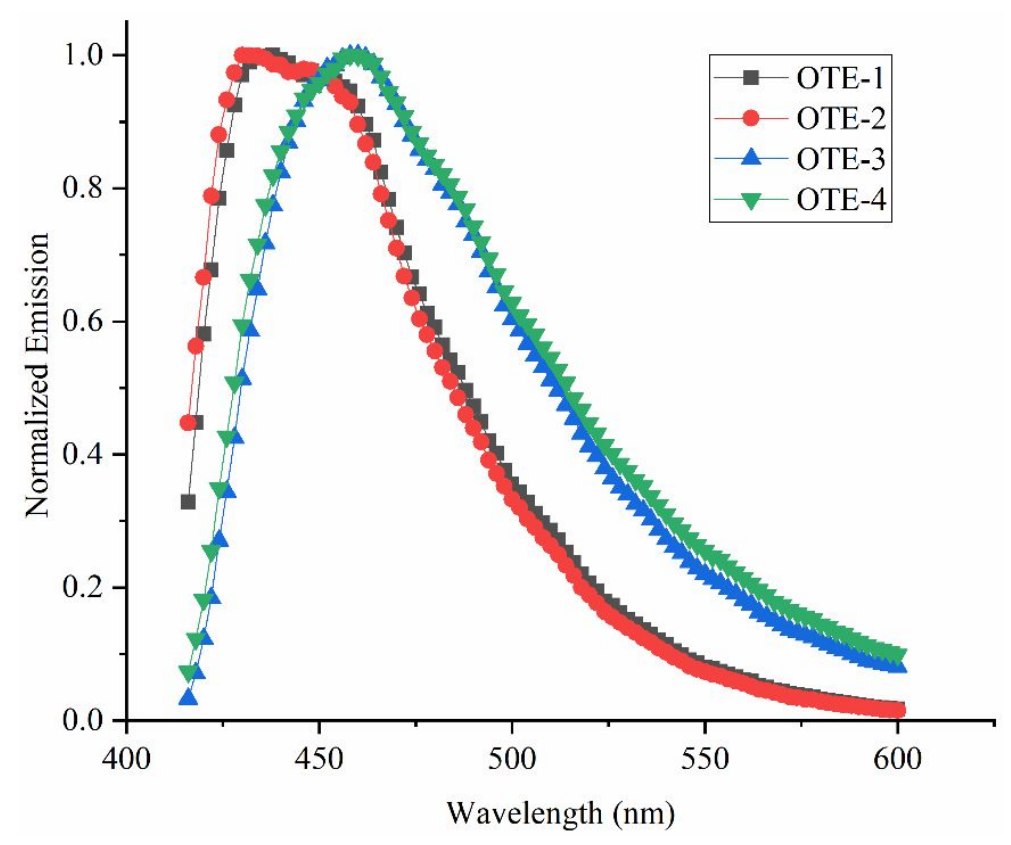

Figure S 36. Fluorescence spectra of OTEs in DMSO.

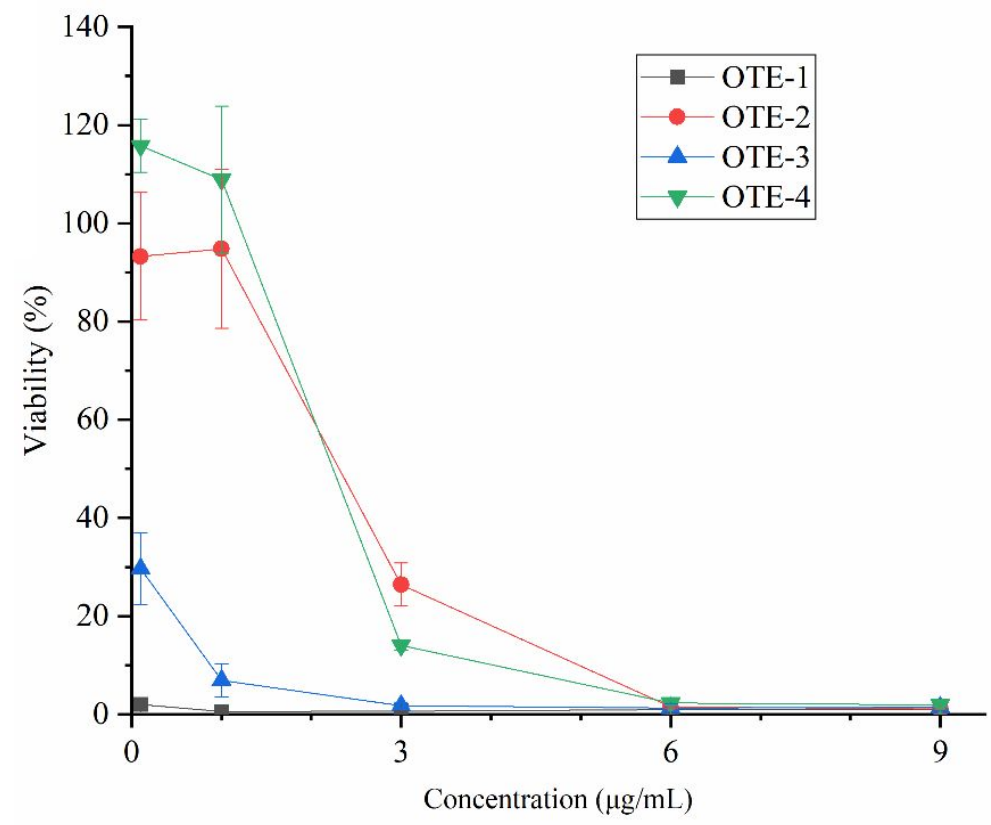

Figure S 37. Cytotoxicity of OTEs against HL-7702 cells. Cells were exposed to OTEs under light $\left(5 \mathrm{~mW} / \mathrm{cm}^{2}\right)$ for $1 \mathrm{~h}$ and then incubated under dark for $24 \mathrm{~h}$ at different concentrations $(n=3)$. 


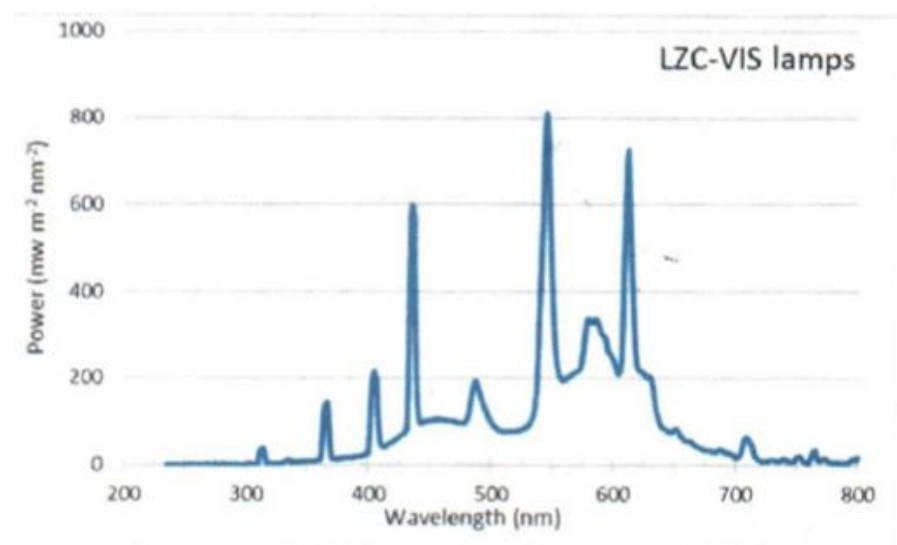

Figure S38. Emission spectrum of LZC-Vis lamps.

Table S1. Zeta potential of $S$. aureus and E. coli incubated with OTEs for $1 \mathrm{~h}$. The concentration of bacteria were about $10^{8} \mathrm{CFU} / \mathrm{mL}$ and the concentration of OTEs were $40 \mu \mathrm{M}$.

\begin{tabular}{lll}
\hline & S. aureus & E. coli \\
\hline OTE-1 & $-12.3 \pm 0.7$ & $-8.5 \pm 0.6$ \\
OTE-2 & $-19.1 \pm 0.5$ & $-9.5 \pm 0.3$ \\
OTE-3 & $-17.6 \pm 0.8$ & $-8.6 \pm 0.5$ \\
OTE-4 & $-8.8 \pm 0.3$ & $-9.2 \pm 0.1$ \\
control & $-21.5 \pm 0.9$ & $-11.7 \pm 0.9$ \\
\hline
\end{tabular}

